\title{
How ideas matter in public policy: a review of concepts, mechanisms, and methods
}

\section{Marij Swinkels}

\section{(2) OpenEdition \\ 1 Journals}

Electronic version

URL: https://journals.openedition.org/irpp/1343

DOI: 10.4000/irpp.1343

ISSN: 2706-6274

Publisher

International Public Policy Association

\section{Printed version}

Date of publication: 15 December 2020

Number of pages: 281-316

ISSN: 2679-3873

\section{Electronic reference}

Marij Swinkels, "How ideas matter in public policy: a review of concepts, mechanisms, and methods", International Review of Public Policy [Online], 2:3 | 2020, Online since 15 décembre 2020, connection on 28 juin 2022. URL: http://journals.openedition.org/irpp/1343 ; DOI: https://doi.org/10.4000/irpp.1343

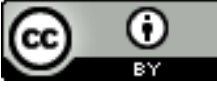




\title{
How ideas matter in public policy: \\ a review of concepts, mechanisms, and methods
}

\author{
Marij Swinkels \\ Utrecht University School of Governance
}

\section{Abstract}

The recent ideational turn in political science and public administration implies that ideas matter. Ideas are an essential explanatory concept for understanding policy changes and decisionmaking processes. The aim of the paper is to specify how ideas matter as a variable in public policy research, providing students and scholars of public policy with a stock take of the current state-of-the-art literature on ideas in political science and public administration. The paper first identifies three approaches to ideas as a variable in the policy process. It then discusses where ideas come from and the dynamics and drivers of ideational change to shed light on the ideational mechanisms underpinning policy processes. Furthermore, it taps into different research methods that can be used to study ideas. Finally, the paper concludes with five lessons for future research endeavours on the study of ideas in public policy.

\section{Keywords}

ideas, beliefs, change, public policy, ideational change, literature review 


\section{Taking stock of how ideas matter}

Public policy studies and political science have experienced an 'ideational turn' in recent years. Ideational explanations have allowed public policy scholars to clarify the content of policy changes and how such changes come about (Béland \& Cox, 2011; Parsons, 2007; Schmidt, 2008). Key research programmes and frameworks in policy sciences, such as Sabatier's Advocacy Coalition Framework, Kingdon's multiple streams approach, and Hall's work on policy paradigms and social learning, have spurred an academic debate on the role of ideas in public policy and political science (Hall, 1993; Kingdon, 1984; Sabatier, 1988). A growing number of studies suggests that ideas are an important variable shaping public policymaking processes (Baumgartner, 2014; Béland \& Cox, 2011; Berman, 2013; Blyth, 2013; Schmidt, 2008). Arguing that 'ideas matter' has become like preaching to the choir: ideational factors are now widely considered an essential variable in the analysis of various political and policymaking phenomena (Kamkhaji \& Radaelli, 2019; Mehta, 2011).

However, ideational scholarship is scattered across subdisciplines, and a comprehensive overview of relevant research questions, findings, and methods is presently lacking. Thus, the analysis of the effects of ideas on public policy is hampered by problems that arise from the imprecise specification of what ideas are, where they come from, when and how they change, and how to study them (Berman, 2013; Carstensen, 2011a; Kamkhaji \& Radaelli, 2019; Meyer \& Strickmann, 2011; Parsons, 2007; Schmidt, 2016). Thus far, ideational scholars have provided us with classifications of different types of ideas (e.g. different levels of generality, ranging from specific policy programmes to overarching cultures) as well as different ways of thinking about ideas (e.g. ranging from positivist to constructivist approaches, stressing ideas as causes of or constitutive of public policy) (cf. Hall, 1993). A result of the concept being used in a variety of subdisciplines is that it has been stretched to include a number of phenomena and concepts, making it close to impossible to understand what is ideational and what is not (Kamkhaji \& Radaelli, 2019). This makes it difficult to understand how ideas matter.

Hence, the aim of this paper is not to reconstruct a succinct overview of the development of ideas in political and policy science. Others have done excellent jobs reviewing the ideational turn in political and policy science (for overviews, see Béland \& Cox, 2011 and Parsons, 2007). Instead, the aim is to provide students and scholars of public policy interested in the concepts of ideas and ideational change with a stock take of the current state of the art to help them navigate the broad interdisciplinary field of ideational scholarship and identify challenges for future ideational scholarship.

To do this, I reviewed articles on ideas and ideational change published over the last 25 years, guided by the PRISMA method (Petticrew \& Roberts, 2006). This research approach allows the researcher to obtain a comprehensive, structured overview of a certain concept or study domain. Using PRISMA for this paper, I obtained an overview of the current literature regarding ideas and ideational change that spans different disciplines. The initial corpus of 71 articles resulting from the analysis was examined thoroughly, and complemented with additional literature. ${ }^{1}$ In sum, most reviewed studies were published by scholars in Anglo-Saxon universities, focusing on the role of ideas in public policy at the national level (specifically in the domains of economic, foreign, or climate policy), and both theoretical and empirical in

1 - PRISMA stands for Preferred Reporting Items for Systematic Reviews and Meta-Analyses. See appendix for an overview of the coding process, background information and data of the reviewed literature, and quantitative overview of the literature that guided this review. Additional literature that complemented the initial corpus was surveyed through conferences, feedback on drafts, and reviews. 
nature (see appendix for full overview of quantitative data about the corpus). A majority of the articles does not specify research design or methodology, data collection techniques or modes of analysis. Furthermore, scanning the corpus suggests that current ideational scholarship is scattered throughout the political and policy science landscape (see Figure 1 in appendix) with little to no cross-fertilisation between journals rooted in different subdisciplines (e.g. political economy and political psychology). This leads to the expectation that there are competing answers regarding four key questions policy researchers should be able to answer when they choose to use ideas as a variable in their research: What is an idea? Where do ideas come from? What are the dynamics and drivers of ideational change? And what methodology can I use to study ideas? Answering these questions will help policy researchers shed light on the pivotal question of how ideas matter in public policy.

The conclusion charts five lessons and objectives for scholars of ideas in public policy research: (1) taking micro-level cognitive dynamics seriously; (2) theorising about relationships between different types of ideas; (3) specifying the conditions, mechanisms, and sequences involved in processes of ideational change; (4) expanding their methodological toolbox with innovative methodologies to measure ideas; and (5) examining the ways in which ideas matter in different policy domains and settings.

\section{Specifying the concept of ideas in public policy}

Policy researchers have come to accept that ideas should be taken seriously as a variable in explanations of public policy outcomes (Cairney, 2019; Mehta, 2011). The corpus used suggests that the relationship between ideas and policy outcomes takes many forms and depends on the precise specification of what ideas are. Concepts associated with ideas are wide-spread, bringing in a 'conceptual minefield' (Berman, 2013; Kamkhaji \& Radaelli, 2019; F. van Esch \& Snellens, 2019). Broadly, ideas can be defined as "beliefs held by individuals or adopted by institutions that influence their actions and attitudes" (Béland \& Cox, 2011, p. 6). Furthermore, scholars seem to assume that what constitutes an idea ranges from specific, programmatic ideas to more general philosophies (Kingdon, 1984; Schmidt, 2008), or from diagnostic beliefs to principled beliefs (cf. Jervis 2006; Van Esch and Snellens 2019).

Simultaneously, the Béland and Cox definition displays the complex and differentiated nature of the concept as a word and emphasises that there are different approaches to determining what ideas are. For instance, stressing ideas as beliefs held by individuals is ontologically different from viewing ideas as embedded entities in institutions. Depending on the chosen perspective, the effect of ideas on policy outcomes may differ, and different mechanisms may cause these effects.

Herein, I unpack Béland and Cox's (2011) definition by reviewing the literature. ${ }^{2}$ The review leads to three broadly different conceptual approaches that scholars working with ideas use across subdisciplines: ideas as sense-making heuristics that guide people's actions, ideas as strategic tools that actors use to craft political discourse, and ideas as institutional frameworks that have an effect on their own and maintain some order throughout the actions of individuals, groups, and society (cf. Blyth, 2001). These approaches vary on their ontological positions on structure and agency and on their epistemological positions on positivism (explaining) and interpretivism (understanding) (Hollis, 1994). Here, in a simplified manner, I address the core positions of these different approaches. 


\section{Ideas as heuristics}

First, ideas can be conceptualised as heuristics or subjective beliefs. ${ }^{3}$ Heuristics are cognitive short-cuts that help people make sense of the complex world around them. Ideas are internalised in people's hearts and mind. People depend on such pre-existing ideas to understand the situations they are in (cf. Jones, 2017).

Scholars term ideas as beliefs, cognitive short-cuts, mental aides, or heuristic devices (Brummer, 2016; Burdein, Lodge \& Taber, 2006; Foyle, 1997; Radaelli \& O’Connor, 2009; Renshon, 2009). A belief system can be defined as a more or less integrated set of beliefs about the human physical and social environment. "An individual's perception, in turn, is filtered through clusters of beliefs or 'cognitive maps' of different parts of his social and physical environment" (Holsti, 1976, p. 20). Thus, ideas act as the filter through which information is viewed and judged (Fielding, Head, Laffan, Western \& Hoegh-Guldberg, 2012; Jacobs, 2009).

Beliefs are subjective as they refer to an individual's understanding of cause-and-effect relationships or normative assumptions about what is good or bad (Jervis, 2006). Beliefs do not provide accurate or objective assertions about the world but 'coloured lenses' through which individuals make sense of the world. This suggests that beliefs limit the capacities of policy actors to review policy debates holistically and constrain the available policy alternatives they consider when making policy decisions.

This approach to ideas originated in foreign policy analysis and political psychology (Jervis, 2006). The fundamental research question asked to understand policy processes, is how to understand what those who make public policy believe. Alexander George (1969, in Larson, 1994) was among the first to develop this approach in political psychology. He proposed that policy actors had a certain 'operational code' consisting of philosophical and instrumental beliefs, setting their parameters for action. This 'opcode' could be constructed through analysis of the verbal behaviour of policy actors.

The pioneer of what recently has started to be referred to as behavioural public administration, Herbert Simon (1947, in Mintrom, 2015), noted early on that any theory of public administration should consider that policy actors are 'boundedly rational'. Therefore, scholars need to grasp how policy actors process information and form views about their decisions. Simon's work found its way into what have become classic policy studies, such as Lindblom's incrementalism, Kingdon's multiple streams, Baumgartner and Jones' punctuated equilibrium, and Sabatier et al.'s Advocacy Coalition Framework.

According to Jones (2017), the 'cognitive approach' focuses on the influence of policy actors' beliefs on policy outcomes, for example by studying the effect of public opinion on the type of policy outcome or the effect of policy-makers' beliefs on policy choices (cf. Yee, 1996). Despite early work denoting that policy actors' beliefs should be taken seriously, many key theories in public policy literature continued to focus on the 'system' as their level of analysis than the individual decision-maker per se. Furthermore, scholars of public administration in part neglected theories and methods from (political) psychology to study these micro-level processes (Grimmelikhuijsen, Jilke, Olsen, \& Tummers, 2017). In recent years, scholars have aimed for cross-fertilisation between public policy theories and (political) psychology theories and methods, with an increasing number of studies on behavioural public administration and the work on micro-foundations in policy learning literature (Dunlop \& Radaelli, 2017; Moyson, Scholten, \& Weible, 2017).

3 - Of $n=71$ articles, $31.0 \%$ of the articles use this conceptualisation. 
In sum, the cognitive approach departs from the micro-level of individual beliefs to explain macro-level phenomena in policymaking. Actors' beliefs constrain or enable them to influence the policymaking process (e.g. agenda-setting, limiting decision-making alternatives, facilitating groupthink). Contemporary questions for this approach centre on how strongly and under what conditions policy actors hold on to which beliefs and examine what causal mechanisms instigate belief changes (cf. Van Esch and Snellens, 2019). In the analysis of study findings in the corpus (see Table 1), both exogenous factors such as crisis, as well as endogenous factors such as the personal disposition of actors' presumably influence the stability of beliefs, leading to competing hypotheses on mechanisms of ideational change (Golec de Zavala \& Van Bergh, 2007; Van Esch \& Swinkels, 2015). Ontologically, scholars in this approach argue that policy action can be primarily explained by examining an individual's 'internal computer'. Epistemologically, this scholarship seeks causal explanations for how such beliefs come about.

\section{Ideas as strategic tools}

Alternatively, scholars take a linguistic, or discursive, approach to ideas and their potential effects on public policy and institutional change. ${ }^{4}$ From this perspective, ideas influence public policy when viewed as the content of discourse (Schmidt, 2008). The role of policy actors is to 'do things with words.' Ideas reflect policy actors' normative orientation towards the context in which they operate, and these determine the behaviour they display in that context (Hay, 2011, p. 67; Blyth, 2001). Scholars of the 'argumentative turn' conceptualise public policy as a social construct (Schon \& Rein, 1995). This requires policy analysts to focus on how policy actors perceive, understand, and frame policy issues, and how they make sense of ideas and imbue them with meaning in the policy process (Hajer \& Wagenaar, 2003).

Despite different orientations within this approach, scholars take argumentation to be essential to grasp how actors perceive the world and interact with their counterparts. Much of the recent interpretive or argumentative work on ideas and public policy centres around discursive institutionalism (Schmidt, 2008). Here, ideas are the substantive content conveyed through the interactive process of discourse. Discourse allows ideas to be generated and communicated in institutional settings (Schmidt, 2011). Change in these institutional settings arises through "dynamic processes through which agents use not only their 'background ideational abilities'... to create and maintain not only their institutions but also their 'foreground discursive abilities' ... to communicate and deliberate about taking action collectively to change (or maintain) those institutions" (Schmidt, 2011: 685). In effect, ideas can be seen as tools purposefully deployed by policy actors to shape the meaning of discourse.

Conceptualising ideas as strategic tools emphasises an active role for actors to consciously work with ideas. Actors engage with ideas, adjust them, and challenge existing ideas through the use of political discourse. Through discursive practice, actors can build coalitions, shape political agendas, navigate the political arena (Morrison, 2016), and effectively induce policy change. This approach is used in different theories of the policy process, for example in the Narrative Policy Framework and the Social Construction Framework (Sabatier \& Weible, 2014). These treat ideas as narrative strategies and social constructions of (groups of) actors.

Policy actors use ideas as rhetorical weapons and armoury in political struggles (McNamara, 1999). If an individual in a group reconfigures the substantive content of an idea he or she holds, the dominant discourse does not necessarily change (yet). Through repeated interaction certain ideas can institutionalise - providing power 'in' ideas (Carstensen \& Schmidt, 2016).

4 - Of $n=71$ articles, $19.7 \%$ of articles use this conceptualisation. 
For example, Schmidt and Thatcher (2014) show the resilience of neoliberal ideas in Europe throughout multiple crises as an effect of the weak substantive content of alternative ideas and the effectiveness of neoliberal ideational entrepreneurs' in political discourse. However, if most people within a policy domain become convinced of the content of alternative ideas, the dominant discourse becomes vulnerable to change and can even disappear. Policy actors potentially have power 'through' ideas, understood as the capacity of actors to persuade other actors to accept and adopt their views through the use of ideational elements (Carstensen \& Schmidt, 2016).

Conceptualising ideas as strategic tools in discourse furthermore links to notions of ideational entrepreneurship or craftsmanship (Bratberg, 2011; Schonhardt-Bailey, 2005). Without strong ideational entrepreneurs, ideas cannot gain prominence in groups or networks. Through positional power and rhetorical skills, entrepreneurs create, represent, promote, and embed group ideas. The key rationale here is that ideas about policy problems or solutions are not a pre-established heuristic device, but are actively constructed through discourse by policy actors (Hajer, 2013; Mehta, 2011; Schon \& Rein, 1995). Hence, this approach is situated at the interpretive side of the epistemological spectrum as opposed to the positivist perspective of the cognitive approach.

This ideational scholarship thus zooms in on the meso-level in policymaking; i.e. how policy actors construct the meaning of public policy through social interaction in groups or in society. Actors are embedded in society but have agency to act and initiate change (Hollis, 1994). Contemporary debate in the ideas-as-strategic-tools approach concerns the extent to which actors are capable of bringing about ideational change as well as the conditions under which they can bring about such change. In sum, when do policy actors gain power 'through' ideas and instigate joint ideational shifts that reconfigure a pre-existing discourse?

\section{Ideas as institutional frameworks}

Third, ideas can be conceptualised as institutional frameworks. ${ }^{5}$ They can be understood as intersubjective understandings embedded in institutions or societies. This approach differs from the heuristics approach, as the causal logic works in reverse. Rather than working their way out from inside people's hearts and minds, ideas work their way into people's hearts and minds from the outside and either hamper or enable them to act. Ideas function as societal norms or paradigms, giving people a sense of direction in uncertain times (Blyth, 2001). Rooted in historical institutionalism, ideas provide policymakers and politicians with "interpretive frameworks that specify the nature of the problems that policy-makers are meant to be addressing" (Hall, 1993, p. 279).

Scholars following this approach refer to ideas as 'blueprints', 'guiding principles', 'philosophies', 'collective systems of thought', 'worldviews', 'ideologies', 'zeitgeist' or 'paradigms' (Bratberg, 2011; Haklai, 2003; Hall, 1993; Rohrschneider, 1993). These specify the set of ideas used for creating public policy (Hogan \& Howlett, 2015). Despite terminological differences, researchers conceive of ideas as mental constructs shared by certain sets of (policy) actors that potentially have an effect on their own (Jacobs, 2015). As these ideas are perceived as widely influential, this makes them often difficult to study (Mehta, 2011).

Ideas can thus give 'organised existence' to a public policy domain (Bell, 2012), representing shared "systems of thought consisting of a series of interconnected claims and assumptions about how something functions" (Baker \& Underhill, 2015, p. 381). Ontologically, ideas are sit-

5 - Of $\mathrm{n}=71$ articles, $27.8 \%$ of articles use this conceptualisation. 
uated at the level of structure. No included study in the review takes a structural-explanatory perspective on ideas. Instead, a structural-interpretive perspective is prevalent. From this perspective, ideas are sets of meaning telling actors how 'to do' social life. Actors are perceived as 'followers' of these sets of meaning (Hollis, 1994). These sets of meaning are open to contestation, but in public policy, the range of potential interpretations is not infinite. Instead, contestation is shaped by path dependency mechanisms (Pierson, 2000) and hegemonic discourses (Blyth, 2013). For example, Matthijs (2016) argued that the ideational construct of ordoliberalism in Germany shaped German policymakers' responses to the Euro crisis. Carstensen and Matthijs (2018) show how the precepts of neoliberalism survived both the global financial crisis and the Euro crisis.

This type of ideational scholarship zooms in on macro-level phenomena in policymaking; i.e. how interpretive policy paradigms govern policy domains. Contemporary questions in this approach are how coherent such ideational frameworks truly are, how change occurs over time, and how such institutional frameworks affect policy debates. Scholars often depart from posthoc analysis of uncertain and complex policy processes. Hence, some scholars render this a problematic approach to studying the impact of ideas on public policy as it fails to account for the cognitive or discursive processes playing a role throughout the policy process (cf. Kamkhaji \& Radaelli, 2019).

\section{Mixed approaches}

Many ideational studies use hybrid conceptual approaches combining elements of the different approaches discussed here.

This blurs the boundaries between ontological and epistemological positions. ${ }^{6}$ For example, studies perceive ideas both as 'worldviews' and shared mental constructs that are used strategically by actors to achieve their goals (cf. Carstensen \& Schmidt, 2016; Helgadottir, 2016; Kuisma, 2013; Parsons, 2016; Saurugger, 2013). This is for good reasons. A one-dimensional focus on ideas as institutional frameworks will tend to leave out a theory of individual action. In contrast, focusing on individual decision-makers only may overemphasise their self-described motivations and exclude the constraints of the social structures under which they are operating (Jacobs, 2015). The 'un-boxability' of these approaches is both a strength and a weakness. The strength of such hybrid approaches is their ability to identify many valuable dimensions of how ideas matter. However, what remains under-theorised is how these different types of ideas relate to one another as a result of competing ontological positions and epistemological views. These imprecise specifications make it easy for other scholars to critique the ideational approach in public policy. Specifying the relationship or interaction between different approaches to a concept allows us to rethink and elaborate on what aspects of the ideational spectrum we study, ultimately spurring our understanding of the potential causal effects of ideas on public policy.

To conclude, ideas can be understood from a cognitive, strategic-discursive, or institutional perspective. Differentiating between these three approaches helps us to answer fundamental questions about where they stand on ontology and epistemology (Hollis, 1994). Cognitive and strategic approaches locate ideas with individuals, whereas the institutional approach locates ideas in structure. A cognitive approach entails a more positivist epistemology, examining causal explanations about how beliefs come about or how they affect policy. Strategic and institutional approaches stand on the interpretive side of the epistemological spectrum, focusing

$6-$ Of $n=71$ articles, $21.5 \%$ of articles used this conceptualisation. 
on how social structures are formed through or structure interpretation and meaning making of policy actors in public policy. Departing from different answers to the question of what ideas are, the question of where ideas come from and how they change is a next step of inquiry into how ideas matter.

\section{Where do ideas in policy processes come from, and what makes them change?}

As Kingdon (1984, p. 72) stated, "ideas can come from anywhere" and also "from a plethora of sources". The question of where ideas come from links to the carriers of ideas in policy processes. As argued above, different ontological positions determine 'who' carries ideas. Different epistemological positions further specify where to look for them. First, from a cognitive approach, ideas, come from 'microfoundations'. Second, a strategic-discursive approach shifts our focus to factors and mechanisms explaining the distribution and transfer of ideas between individuals or between individuals and groups (micro- to micro- or micro- to mesolevel). Alternatively, ideas can be seen as epiphenomenal frameworks (Kamkhaji \& Radaelli, 2019). This shifts the focus to factors such as time, context, and events to explain how taken-for-granted ideas in a policy domain may be altered.

How ideas form and how they change, in short, draws our attention to both institutional and contextual (exogenous) factors as well as actor-specific and entrepreneurial (endogenous) factors (see Table 1 for a full overview). Relating different types of factors to who 'carries' ideas leads to the identification of different mechanisms of ideational change. For example, from an agency-endogenous perspective, identified mechanisms of ideational change include: (instrumental and social) learning, input, persuasion, puzzling (Van Esch \& Snellens, 2019). These mechanisms all refer to processes in which policy actors try to make sense of new or alternative ideas in different ways. From a structural-endogenous perspective, mechanisms such as socialisation, imitation or identification describe how policy actors adapt to ideas in a social context. From an exogenous-agency perspective, mechanisms of ideational change are more 'political' and include coercion, powering, or turn-over. Alternatively, from a structural-exogenous perspective, ideational change occurs through dispersion. Ideas then spread among human beings more or less the same way as germs or viruses do (cf. Dunlop \& Radaelli, 2017; Moyson et al., 2017 and Van Esch \& Snellens, 2019 for a more in-depth discussion of alternative mechanisms of ideational change). In the discussion below, I discuss the three most dominant mechanisms identified in our initial corpus of ideational studies related to ideational change: learning, persuasion and socialisation. ${ }^{7}$ As studies in our corpus often identified endogenous factors as triggers for change, while identifying exogenous factors as a scoping condition for change, it makes sense that these three mechanisms are most prevalent in the reviewed corpus.

\section{Ideas come from microfoundations}

Microfoundations refers to understanding public policy as the aggregate of policy actors' behaviour. If ideas affecting policymaking originate in the cognition of individual policy actors, then a logical second step is to examine what factors influence cognition (e.g. openness to information, education, emotion, experience) as well as when and how these factors contribute to changes in cognition (Brummer, 2016; Kamkhaji \& Radaelli, 2017). The corpus included studies into the effects of personal disposition on both the content and flexibility of policy actors' ideas in policy processes (see Table 1 for a complete overview of expectations and findings

7 - For analytical purposes, this overview is presented in a somewhat arbitrary manner. In reality, the literature is more intertwined at times. 
of the included studies). For example, studies on the effect of cynicism, values, level of education, anxiety, and arousal have demonstrated that these factors affect the core meaning of the beliefs of individual actors in policy processes (cf. Bolsen, Druckman \& Cook, 2015; Brewer \& Steenbergen, 2002; Fielding et al., 2012). These studies discovered a positive relation between these factors and their influence on the beliefs of policy actors. For example, Fielding et al. (2012) showed how personal disposition (e.g. level of education) is positively associated with politicians' belief in climate change and this guides their response to policy issues (see Table 1).

Other studies have examined the effect of personal disposition on the stability or flexibility of beliefs as a proxy for their receptivity to new, alternative policy ideas (see Table 1), for example the effects of traits, expertise, partisanship, and emotion on belief stability. For instance, Brummer (2016) suggested a relationship between a political leader's openness to information and their reflective stance towards new policy ideas. As a result, openness to information could decrease the likeliness of leaders to become involved in policy fiascos. Meanwhile, expertise is seen as a constraining factor for belief change (cf. Larson, 1994). Emotions, such as anxiety, could prefigure the beliefs of elites (Renshon, Lee \& Tingley, 2015; Widmaier, 2010). These factors could make policy actors less prone to belief changes, ultimately affecting policy stability.

The oft-used causal mechanism through which an individual actor is believed to change their cognitive ideas is instrumental learning (Van Esch \& Snellens, 2019). Learning in this sense refers to the 'updating of beliefs' (Dunlop \& Radaelli, 2013, p. 599). Through learning, actors can stick to, reinforce, or revise their ideas about public policy (Trein \& Vagionaki, 2020, p. 8) According to the literature, learning is more likely to occur under scoping conditions of crisis, external challenges, discrepant events, and failures. Scoping conditions in this sense refers to the context in which a particular mechanism is theorised as likely to be activated (Beach \& Pedersen, 2013). Cognitive-ideational scholars often choose such scoping conditions as the empirical research environment in which to study if and when learning occurs. The need to respond to scoping conditions, which generate uncertainty about existing beliefs and the policies based on them, may set people on the path of learning. However, depending on the personal disposition of actors, such challenging circumstances could also produce impulses to adhere to and defend existing ideas (Van Esch, 2014). From a cognitive perspective, it is, therefore, questionable whether political actors are as prone to ideational change as people tend to think. People are often rigid and resistant to new ideas, even under crisis conditions (Moyson, 2017).

In conclusion, the policy process is permeated by the beliefs of individual policy actors and their beliefs are conditioned by cognitive processes. The personal disposition of policy actors determines their receptivity to new, alternative ideas in response to scoping conditions (e.g. crises, exogenous shocks). As such, only when learning occurs and actors update their beliefs in response to new circumstances can we find an effect on policy change.

\section{Ideas come from interaction and entrepreneurship between policy actors}

Scholars taking a discursive approach depart from the assumption that ideas are tools for policy actors to transfer and distribute in groups or networks. Questions of ideational change do not centre so much on the stringency or flexibility of ideas, but on questions of reconfiguration or convergence and divergence of ideas. As such, studying the effect of ideas on public policy concerns the ways in which ideas are transmitted in policy processes. Ideational research in this stream takes us to the study of policy entrepreneurs and their capacities to transmit ideas in networks, advocacy groups, and epistemic communities. The concept of policy entrepreneurs was first established by Kingdon (1984) and refers to policy actors capable of linking 
policy problems to policy ideas to promote policy decisions. Yet, a major challenge ahead lies in the ways in which such communicative interactions of policy entrepreneurs truly function as an explanation of policy processes.

Scholars surmise that the positions of and power divisions between policy actors within existing policy networks, the availability of new ideas, and their rhetorical skills to promote them determine which actors become key entrepreneurs in the transfer and distribution of ideas (Moschella, 2015) (see Table 1). Policy entrepreneurs need considerable resources, legitimacy, and a feasible alternative to the institutional status quo. Organisational or institutional settings play a role in determining who is 'waiting in the wings' and has the resources and positions of authority to become a policy entrepreneur (see Table 1 - institutional factors). For example, policy experts in a policy subsystem with a high degree of autonomy are more often in a position to introduce radical new ideas into the policy process (Baker, 2015). Helgadóttir (2016) argued that influential Italian economic policy ideas could be advanced and diffused throughout the EU as a result of putting people in the right positions.

Once policy entrepreneurs are in place, they can become the 'central defecting actors', creating windows of opportunity for policy change. To do so, they need to persuade other actors that their old ideas are wrong and instigate a 'joint belief shift' (Culpepper, 2005, p. 176). Whether the entrepreneurs are successful in bringing about such shifts depends on the different strategies they deploy (see Table 1). Strategies range from effective problem framing to team building, assembling new evidence, and collaborating with advocacy coalitions or policy networks to use and expand network connectedness (Petridou \& Mintrom, 2020). If entrepreneurs have rhetorical skills, they may succeed in making certain ideas more or less attractive (Béland \& Cox, 2016). For instance, the French Mont Pélerin society meetings were used by policy entrepreneurs to transmit the idea of neoliberalism into the public realm (Schmidt \& Thatcher, 2014). Successful 'idea carriers' are often political and administrative elites that have authority on the basis of their expertise, experience, position, and skills.

The causal mechanism to explain how policy entrepreneurs can evoke ideational change is persuasion. Mobilising language leads people to adopt or adapt to the new or alternative ideas that policy entrepreneurs present to them (Béland, 2016; Kuisma, 2013). Persuasion may result in a consensus (convergence of ideas) among different actors participating in policy debates (Baker, 2015; Bell \& Hindmoor, 2015). This mechanism arguably plays a role in highly politicised contexts (with much ideological disparity) wherein multiple, equally powerful actors try to move each other by argument (Flibbert, 2006).

The assumption that ideas originate in the interactions between policy actors has two analytical consequences. First, if change results from interaction, it implies a more active and influential role of policy actors in the policy process (Trein \& Vagionaki, 2020). Second, it implies that they are not necessarily coherent entities but composed of different elements that policy actors piece together. Through bricolage, policy actors piece together different elements of meaning to construct a 'web of meaning' (Carstensen, 2011b). Seen from this perspective, ideas are flexible, open, fluid, and always subject to contestation (Crawford, 2016).

In conclusion, the literature on the transfer and diffusion of ideas stresses the importance of studying who becomes a policy entrepreneur and the discursive strategies they use to persuade others of (alternative) ideas towards public policy. Institutional and structural factors predetermine which actors could potentially play a role in changing ideas in policy processes, whereas the successful uptake of new ideas by others is the result of the discursive strategies these actors deploy. 


\section{Ideas come from processes of institutionalisation}

Taking a structural perspective of ideas, ideas seemingly 'float freely' and cannot be attributed to specific individuals per se. Policy actors are mere followers of social structures and choices they make follow from given conditions in their environment (Parsons, 2007). Alterations in these stable, institutional ideas are often observed through critical analysis, highlighting the retrospective distinction between policy paradigms such as Keynesianism and Monetarism (Hall, 1993). Paradigmatic ideas, such as neoliberalism, may be quite resilient and coherent (cf. Schmidt \& Thatcher, 2014). The timeframe to study such processes of change is lengthier: explaining the emergence of such institutional frameworks requires careful process-tracing, often analysing the development of a policy domain over a long time-span, carefully reconstructing the history of such frameworks (Jacobs, 2015; Mehta, 2011).

It is appealing to believe that factors sweeping ideas aside are contextual, for example through emerging external challenges like a crisis (Cairney, 2019) (see Table 1). Schmidt (2016) showed how the contextual pressure of the Eurozone crisis made German policymakers question their taken-for-granted ordoliberal ideas for the first time since these ideas had been first formed in the 1950s. Baker and Underhill (2015) argued that the global financial crisis opened a window of opportunity for actors to push new economic ideas and instigate policy reforms, countering prevailing post-Keynesian ideas in place since the 1990s. As such, one could argue that exogenous shocks can serve as an explanatory concept for deep ideational change. In effect, it disregards both the cognitive and discursive ideational processes that occur in between (Kamkhaji \& Radaelli, 2019).

A more fine-grained observation renders the process of change to be 'layered'. Here, external challenges do not provide a full explanation of why some ideas come into being instead of others. Acknowledging that new ideas first develop in the cognition of individual actors, and are subsequently communicated through discourse, allows for an analysis of how more actors come to a 'buy-in' of new ideas that may replace a prevailing interpretive paradigm. This provides a more gradual explanation of ideational change. Through individual learning and collective interaction, the majority of policy actors may ultimately be socialised into a new interpretive paradigmatic framework.

Socialisation is the mechanism through which actors or groups become a part of institutional practices, rules, or norms. It occurs as a result of observing or simulating existing practices (e.g. Bell, 2012) and creates stable policy communities that could potentially become infected with new ideas. Saurugger (2013, p. 894) stated that, "Socialization occurs when norms, worldviews, collective understandings are internalized, and subsequently are codified by a group of actors". Adapting to ideas through socialisation is characterised in the literature as 'mimesis', 'imitation', or 'internalisation' (Becker \& Hendriks, 2008).

In sum, once ideas are institutionalised, they are believed to sit at the 'deepest level of generality' (Schmidt, 2016, p. 320). They arrive there as the result of a process preceded by individual learning and collective interaction, wherein the historical and political context of a policy domain and its actors influence how ideas institutionalise over time. The extent to which the historical and political context determine institutionalisation through time vis-à-vis the involvement of active, strategic entrepreneurs influencing this process is a key question in the literature. Pinning down the exact moments when transitioning actors become aware of their background ideas, start learning, and subsequently start using them strategically in political discourse is a less empirically assessed topic (Molthof, 2016). 
To conclude, ideas may 'come from anywhere', but I have provided clues about where to look for them and what range of factors and mechanisms influence ideational change. For reference, Table 1 shows a more complete overview of specific hypotheses that ideational scholars in the reviewed literature have both formulated and examined to understand the different types of ideas and ideational change. In addition to the general discussion above, this overview could help scholars formulate expectations and hypotheses for future explorations of ideational change, aiding them in their examination of 'how' specific ideas matter in policymaking.

Table 1: triggers and constraints for ideational change

\begin{tabular}{|c|c|c|c|c|}
\hline Factors & Effects of... & Effects on... & $\begin{array}{l}\text { Effect or } \\
\text { proposition }\end{array}$ & Findings \\
\hline \multirow[t]{4}{*}{$\begin{array}{l}\text { Institutional / } \\
\text { Political }\end{array}$} & Partisanship & $\begin{array}{l}\text { 1. Ideational } \\
\text { stability/ } \\
\text { rigidity } \\
\text { 1. Ideational } \\
\text { divergence }\end{array}$ & $\begin{array}{l}\text { 1. Positive } \\
\text { 2. Positive }\end{array}$ & $\begin{array}{l}\text { 1. Significant relation partisanship and } \\
\text { stability of beliefs about global warm- } \\
\text { ing (Bolsen et al., 2015; Clements, } \\
\text { 2012; Fielding et al., 2012) } \\
\text { 2. Partisanship severely hindered } \\
\text { ideological consensus for policy mak- } \\
\text { ing (Campbell \& Pedersen, 2015). } \\
\text { Ideological difference of left-wing gov- } \\
\text { ernments and IMF staff results in few- } \\
\text { er waivers (Nelson, 2014). }\end{array}$ \\
\hline & Elections & $\begin{array}{l}\text { 1. Ideational } \\
\text { stringency/ } \\
\text { flexibility } \\
\text { 2. Ideational } \\
\text { consensus/ } \\
\text { dissensus }\end{array}$ & $\begin{array}{l}\text { 1. Positive } \\
\text { 2. Positive }\end{array}$ & $\begin{array}{l}\text { 1. Post-election effect on leni- } \\
\text { ency of beliefs of IMF staff to bor- } \\
\text { rowing countries (Nelson, 2014). } \\
\text { Suspension of alternative ideas un- } \\
\text { til after elections (Morrison, 2016). } \\
\text { Béland and Waddan (2015): few pos- } \\
\text { sibilities for challenging existing ideas } \\
\text { during elections in UK political institu- } \\
\text { tions. } \\
\text { 2. Outcome German election in 2009 } \\
\text { undermined dominant ideational con- } \\
\text { sensus in EMU (Matthijs, 2016). }\end{array}$ \\
\hline & $\begin{array}{l}\text { Presence of } \\
\text { veto players }\end{array}$ & $\begin{array}{l}\text { Ideational } \\
\text { stasis/strin- } \\
\text { gency }\end{array}$ & Positive & $\begin{array}{l}\text { Successful introduction of ideas about } \\
\text { policy as, in part, result of silencing } \\
\text { veto players (Mandelkern \& Shalev, } \\
\text { 2010). } \\
\text { Baker (2015): eliminating veto players } \\
\text { in financial regulation led to ideational } \\
\text { change. }\end{array}$ \\
\hline & $\begin{array}{l}\text { Centralised } \\
\text { institutions }\end{array}$ & $\begin{array}{l}\text { Ideational } \\
\text { stringency }\end{array}$ & Positive & $\begin{array}{l}\text { Organisational strength led to coher- } \\
\text { ent environmental belief system in NL } \\
\text { and GE (Rohrschneider, 1993). }\end{array}$ \\
\hline
\end{tabular}




\begin{tabular}{|c|c|c|c|}
\hline $\begin{array}{l}\text { Network } \\
(\text { com)posi- } \\
\text { tion }\end{array}$ & $\begin{array}{l}\text { Ideational } \\
\text { diffusion or } \\
\text { convergence }\end{array}$ & Mixed & $\begin{array}{l}\text { Knowledge regime structure affected } \\
\text { ideational diffusion / convergence in } \\
\text { France and Germany (Campbell \& Ped- } \\
\text { ersen, 2015). } \\
\text { Becker and Hendriks (2008): position } \\
\text { of epistemic community close to gov- } \\
\text { ernment influences ideational diffu- } \\
\text { sion. }\end{array}$ \\
\hline $\begin{array}{l}\text { High } \\
\text { autonomy } \\
\text { of policy } \\
\text { experts }\end{array}$ & $\begin{array}{l}\text { Radical } \\
\text { ideational } \\
\text { change }\end{array}$ & Mixed & $\begin{array}{l}\text { Autonomy of policy experts in policy } \\
\text { subsystems of macroeconomic policy } \\
\text { and financial regulation affects idea- } \\
\text { tional change differently as result of } \\
\text { institutional barriers (Baker, 2015). }\end{array}$ \\
\hline $\begin{array}{l}\text { Policy do- } \\
\text { main }\end{array}$ & $\begin{array}{l}\text { Ideational } \\
\text { convergence }\end{array}$ & Mixed & $\begin{array}{l}\text { Radaelli and O'Connor (2009): shared } \\
\text { governance beliefs about EU matter } \\
\text { more for convergence than policy be- } \\
\text { liefs. No support for hypothesis that } \\
\text { members of supranational commit- } \\
\text { tees have more common beliefs than } \\
\text { members of intergovernmental com- } \\
\text { mittees. } \\
\text { Baker (2015): depending on institu- } \\
\text { tional structures different effects on } \\
\text { convergence. }\end{array}$ \\
\hline $\begin{array}{l}\text { Bureaucratic } \\
\text { culture }\end{array}$ & $\begin{array}{l}\text { Ideational } \\
\text { stasis }\end{array}$ & Positive & $\begin{array}{l}\text { Moschella (2015): strong bureaucratic } \\
\text { culture in IMF leads to ideational } \\
\text { stasis. }\end{array}$ \\
\hline $\begin{array}{l}\text { Professional } \\
\text { position/ } \\
\text { role }\end{array}$ & $\begin{array}{l}\text { Ideational } \\
\text { dominance }\end{array}$ & Mixed & $\begin{array}{l}\text { Alan Greenspan's position as FED di- } \\
\text { rector constrained idea of macropru- } \\
\text { dentialism (Baker, 2013). } \\
\text { Widmaier (2007): false expectation, } \\
\text { more related to 'how you think' rather } \\
\text { than 'where you sit'. } \\
\text { Woods (1995): recruitment processes, } \\
\text { civil service appointments, position of } \\
\text { agencies influence why particular ideas } \\
\text { are chosen at expense of others. } \\
\text { Helgadottir (2016): sitting at key posi- } \\
\text { tions in institutions enables spread of } \\
\text { ideas. }\end{array}$ \\
\hline
\end{tabular}




\begin{tabular}{|c|c|c|c|c|}
\hline & $\begin{array}{l}\text { (Strong) } \\
\text { Mandate }\end{array}$ & $\begin{array}{l}\text { Incremental } \\
\text { ideational } \\
\text { change }\end{array}$ & Positive & $\begin{array}{l}\text { Moschella (2015): IMF's institution- } \\
\text { al mandate (Articles of Agreement) } \\
\text { lead to incremental, path-dependent } \\
\text { changes in ideas about capital controls. } \\
\text { Hall (1993) significant shifts in au- } \\
\text { thority over policy expertise precedes } \\
\text { paradigmatic ideational change. }\end{array}$ \\
\hline \multirow[t]{8}{*}{ Disposition } & $\begin{array}{l}\text { (high) } \\
\text { Cognitive } \\
\text { complexity }\end{array}$ & $\begin{array}{l}\text { Ideological } \\
\text { reflection } \\
\text { and learning }\end{array}$ & Proposition & $\begin{array}{l}\text { Brummer (2016): suggests relation } \\
\text { between openness to information and } \\
\text { reflective stance towards other, alter- } \\
\text { native ideas (not empirically assessed). }\end{array}$ \\
\hline & $\begin{array}{l}\text { (high) Need } \\
\text { for closure }\end{array}$ & $\begin{array}{l}\text { Ideological } \\
\text { stringency }\end{array}$ & Positive & $\begin{array}{l}\text { Effect of the trait 'need for closure' on } \\
\text { stability of worldview (Golec de Zavala } \\
\text { \& Van Bergh, 2007). }\end{array}$ \\
\hline & $\begin{array}{l}\text { Social con- } \\
\text { formity }\end{array}$ & $\begin{array}{l}\text { Core mean- } \\
\text { ing of ideas }\end{array}$ & Positive & $\begin{array}{l}\text { Significant relation social conformity } \\
\text { and idea of the world as threatening } \\
\text { place (Duckitt \& Fisher, 2003). }\end{array}$ \\
\hline & Cynicism & $\begin{array}{l}\text { Core mean- } \\
\text { ing of ideas }\end{array}$ & Positive & $\begin{array}{l}\text { Brewer and Steenbergen (2002): cyni- } \\
\text { cal respondents more likely to support } \\
\text { idea of increased defense spending. }\end{array}$ \\
\hline & Values & $\begin{array}{l}\text { Core mean- } \\
\text { ing of ideas }\end{array}$ & Positive & $\begin{array}{l}\text { Support for hypothesis that people } \\
\text { with egalitarian values have more be- } \\
\text { lief in fact that global warming is hap- } \\
\text { pening (Bolsen et al., 2015). }\end{array}$ \\
\hline & Anxiety & $\begin{array}{l}(\mathrm{Re}){ }_{\text {con- }} \\
\text { figuration of } \\
\text { ideas }\end{array}$ & Proposition & $\begin{array}{l}\text { Widmaier (2010): proposes that elite } \\
\text { anxiety about populism prefigures par- } \\
\text { adigmatic views of elites. }\end{array}$ \\
\hline & $\begin{array}{l}\text { Physiological } \\
\text { arousal }\end{array}$ & $\begin{array}{l}\text { Core mean- } \\
\text { ing of ideas }\end{array}$ & $\begin{array}{l}\text { Mediating } \\
\text { effect }\end{array}$ & $\begin{array}{l}\text { Heightened arousal mediates relation } \\
\text { between anxiety and beliefs about mi- } \\
\text { grants (Renshon et al., 2015). }\end{array}$ \\
\hline & $\begin{array}{l}\text { (similar) } \\
\text { educational } \\
\text { background }\end{array}$ & $\begin{array}{l}\text { 1. Ideational } \\
\text { formation } \\
\text { 2. Ideational } \\
\text { convergence }\end{array}$ & 1. Mixed & $\begin{array}{l}\text { 1. Non-significant relationship } \\
\text { educational background and for- } \\
\text { mation of beliefs (Morcol, 2001). } \\
\text { Nelson (2014: 312): 'graduate train- } \\
\text { ing in economics "is a transformative } \\
\text { experience for doctoral students that } \\
\text { creates strong professional identities."' } \\
\text { 2. Helgadottir (2016): power of aca- } \\
\text { demic 'Bocconi' network on promoting } \\
\text { idea of expansionary austerity in eco- } \\
\text { nomic policy-making sphere. }\end{array}$ \\
\hline
\end{tabular}




\begin{tabular}{|c|c|c|c|c|}
\hline & Expertise & $\begin{array}{l}\text { Ideational } \\
\text { stringency }\end{array}$ & Proposition & $\begin{array}{l}\text { Larson (1994): suggests experts have } \\
\text { more constrained belief systems. } \\
\text { Butler et al. (1995): suggest relation } \\
\text { expertise and lower attitude change } \\
\text { due to ability to counterargue and en- } \\
\text { gage in critical thinking. } \\
\text { Widmaier (2016): belief in own (mac- } \\
\text { roeconomic) expertise may lead to un- } \\
\text { derrate potential market changes and } \\
\text { felt need to adjust own ideas. }\end{array}$ \\
\hline & $\begin{array}{l}\text { Gender, age, } \\
\text { religion, } \\
\text { education }\end{array}$ & $\begin{array}{l}\text { Core mean- } \\
\text { ing of ideas }\end{array}$ & Positive & $\begin{array}{l}\text { Gender, age, education have signifi- } \\
\text { cant effect on beliefs about environ- } \\
\text { ment (Clements 2012). Strong relation } \\
\text { between religion and beliefs about en- } \\
\text { vironment (Guth, Green, Kellstedt, \& } \\
\text { Smidt, 1995). } \\
\text { Highly educated more belief in climate } \\
\text { change (Fielding et al., 2012). }\end{array}$ \\
\hline \multirow[t]{2}{*}{$\begin{array}{l}\text { Strategies and } \\
\text { skills }\end{array}$} & $\begin{array}{l}\text { Strong rhe- } \\
\text { torical skills } \\
\text { (crafting and } \\
\text { promoting } \\
\text { ideas) }\end{array}$ & $\begin{array}{l}\text { Ideational } \\
\text { reconfigura- } \\
\text { tion }\end{array}$ & Positive & $\begin{array}{l}\text { Abilities of policy entrepreneurs to } \\
\text { craft, promote and work with the idea } \\
\text { (rhetorical skill) make certain ideas } \\
\text { more or less attractive (coalition mag- } \\
\text { nets) (Béland \& Cox, 2016). } \\
\text { Flibbert (2006): strong persuasive } \\
\text { skills bridge ideological divergence and } \\
\text { can create broad ideological consensus } \\
\text { (about going to war). } \\
\text { Finnemore and Sikkink (1998): some } \\
\text { carriers of ideas are more likely to } \\
\text { spread ideas than others. }\end{array}$ \\
\hline & $\begin{array}{l}\text { Promoting } \\
\text { ambiguity, } \\
\text { prominence, } \\
\text { attractive- } \\
\text { ness }\end{array}$ & $\begin{array}{l}\text { Ideational } \\
\text { traction / } \\
\text { convergence }\end{array}$ & Proposition & $\begin{array}{l}\text { Parsons (2016): when ideas have ca- } \\
\text { pacity to be understood in multiple } \\
\text { ways, combining shared and unshared } \\
\text { interpretations, more convergence. } \\
\text { Provides example of European market } \\
\text { integration. } \\
\text { Finnemore and Sikkink (1998): intrin- } \\
\text { sic characteristics determine influence } \\
\text { of ideas. } \\
\text { Cox and Béland (2013): high valence of } \\
\text { sustainability (emotional quality of an } \\
\text { idea) leads to more entrepreneurs us- } \\
\text { ing it. }\end{array}$ \\
\hline
\end{tabular}




\begin{tabular}{|c|c|c|c|c|}
\hline & $\begin{array}{l}\text { Discursive } \\
\text { abilities of } \\
\text { actors }\end{array}$ & $\begin{array}{l}\text { Ideational } \\
\text { formation/ } \\
\text { conversion }\end{array}$ & Positive & $\begin{array}{l}\text { Hall (2013): role of media getting mon- } \\
\text { etarist ideas on public agenda. } \\
\text { Carstensen (2010): discursive power } \\
\text { of lib-dem government to convert the } \\
\text { idea of individualisation to gain sup- } \\
\text { port for their reform ideas. } \\
\text { Mandelkern and Shalev (2010): in eco- } \\
\text { nomic policy reform, two similar plans } \\
\text { had different fates as result of idea- } \\
\text { tional entrepreneurs who promoted } \\
\text { them. } \\
\text { Schmidt (2016): engagement in com- } \\
\text { municative discourse leads to adoption } \\
\text { of ideas by public. }\end{array}$ \\
\hline & $\begin{array}{l}\text { Using and } \\
\text { expanding } \\
\text { networks } \\
\text { (conferenc- } \\
\text { es, network } \\
\text { meetings) }\end{array}$ & $\begin{array}{l}\text { Ideational } \\
\text { formation } \\
\text { (receptivity) }\end{array}$ & Proposition & $\begin{array}{l}\text { Flibbert (2006): close ties between } \\
\text { policy intellectuals and the administra- } \\
\text { tion determine what ideas are taken up } \\
\text { and gain prominence. } \\
\text { Schmidt (2016): Mont Perlin Society } \\
\text { meetings allowed transmission of neo- } \\
\text { liberalism. }\end{array}$ \\
\hline & $\begin{array}{l}\text { (different) } \\
\text { motives }\end{array}$ & $\begin{array}{l}\text { Ideational } \\
\text { change }\end{array}$ & Proposition & $\begin{array}{l}\text { Schmidt (2016): Ideologically (Thatch- } \\
\text { er), opportunistic (Chirac, Berlusconi, } \\
\text { Sarkozy), and pragmatic (Erhard, } \\
\text { Blair, Schröder) entrepreneurs' ability } \\
\text { to 'craft' and disseminate ideas about } \\
\text { neoliberalism, although they have dif- } \\
\text { ferent motives. }\end{array}$ \\
\hline & $\begin{array}{l}\text { Introducing } \\
\text { (new) knowl- } \\
\text { edge }\end{array}$ & $\begin{array}{l}\text { Type of } \\
\text { ideational } \\
\text { change }\end{array}$ & Mixed & $\begin{array}{l}\text { Moschella (2015): new research and } \\
\text { strategic advocates in IMF undermined } \\
\text { existing ideas about economic growth } \\
\text { - allowing for incremental change. } \\
\text { Baker (2015): new information show- } \\
\text { ing inconsistencies in paradigm led to } \\
\text { fundamental macroeconomic change. }\end{array}$ \\
\hline Contextual & $\begin{array}{l}\text { (economic) } \\
\text { distress }\end{array}$ & $\begin{array}{l}\text { 1. Salient } \\
\text { ideational } \\
\text { change } \\
\text { 2. Radical } \\
\text { ideational } \\
\text { change. }\end{array}$ & $\begin{array}{l}\text { 1. Positive } \\
\text { 2. Proposi- } \\
\text { tion }\end{array}$ & $\begin{array}{l}\text { 1. Cox and Béland (2013): growing un- } \\
\text { certainty about economic conditions } \\
\text { led to rise of idea of sustainability in } \\
\text { different policy domains. } \\
\text { 2. Baker and Underhill (2015): suggest } \\
\text { effect of financial distress on macro- } \\
\text { prudential ideas. }\end{array}$ \\
\hline
\end{tabular}




\begin{tabular}{|c|c|c|c|}
\hline $\begin{array}{l}\text { Inadequate } \\
\text { resources } \\
\text { and emerg- } \\
\text { ing external } \\
\text { challenges }\end{array}$ & $\begin{array}{l}\text { Probability } \\
\text { for ideation- } \\
\text { al learning }\end{array}$ & Proposition & $\begin{array}{l}\text { Schmidt (2016): Eurozone crisis first } \\
\text { time that German ordoliberal ideas } \\
\text { were actively questioned. }\end{array}$ \\
\hline $\begin{array}{l}\text { Economic } \\
\text { asymmetries } \\
\text { and domes- } \\
\text { tic spending } \\
\text { changes }\end{array}$ & $\begin{array}{l}\text { Ideational } \\
\text { flexibility }\end{array}$ & Mixed & $\begin{array}{l}\text { Lee (2016): finance-heavy crises, size } \\
\text { of financial sector, and decline in com- } \\
\text { petitiveness lead to alternative, less } \\
\text { strict, ideas about regulation. Evidence } \\
\text { shows how material factors drove both } \\
\text { public and elite ideas about regulation. } \\
\text { Meyer and Strickmann (2011) pose } \\
\text { these as propositions and present ex- } \\
\text { ample of EU defence policy. }\end{array}$ \\
\hline $\begin{array}{l}\text { Exogenous } \\
\text { shock/un- } \\
\text { certainty/ } \\
\text { window of } \\
\text { opportunity }\end{array}$ & $\begin{array}{l}\text { Radical } \\
\text { ideational } \\
\text { change (de- } \\
\text { institution- } \\
\text { alizing) }\end{array}$ & Mixed & $\begin{array}{l}\text { Baker and Underhill (2015): GFC } \\
\text { opened up a window of opportunity for } \\
\text { agents of change and norm entrepre- } \\
\text { neurs to push new ideas, yet this took } \\
\text { place within a pattern of 'path depend- } \\
\text { ency' underpinned by vested interests. } \\
\text { Baker (2015): macroeconomic failure } \\
\text { lead to fundamental macroeconomic } \\
\text { change. } \\
\text { Hall (1993) shift from Keynesian to } \\
\text { monetarist paradigm as result of accu- } \\
\text { mulation of anomalies and failure. } \\
\text { Flibbert (2006): September 11 changed } \\
\text { individual beliefs about national and } \\
\text { personal security. } \\
\text { Mandelkern \& Shalev (2010): absence } \\
\text { of window of opportunity made inno- } \\
\text { vation of ideas highly difficult. } \\
\text { Bratberg (2011): windows of opportu- } \\
\text { nity gave both Blair and Chirac options } \\
\text { to become successful ideational entre- } \\
\text { preneurs and change existing ideas. } \\
\text { Jacobs (2009): global depression re- } \\
\text { versed logic of policy officials about } \\
\text { pension system. }\end{array}$ \\
\hline $\begin{array}{l}\text { Domestic } \\
\text { turmoil }\end{array}$ & $\begin{array}{l}\text { Ideational } \\
\text { adaptation }\end{array}$ & Proposition & $\begin{array}{l}\text { Finnemore and Sikkink (1998): domes- } \\
\text { tic turmoil opens up window of oppor- } \\
\text { tunity to push through new norms. }\end{array}$ \\
\hline
\end{tabular}




\section{Methods to study ideas}

Adding to the theoretical challenges concerning ideas and ideational change, ideational scholarship also harbours methodological challenges. One key challenge is how ideas can be measured. For example, much ideational scholarship builds on hypothesised assumptions of how cognitive ideas influence public policy but does not necessarily provide methods to do so (Kamkhaji \& Radaelli, 2019). Hence, in some aspects, the field of ideational studies remains methodologically underdeveloped.

So how can ideas be empirically established and what data sources could be used to study them? In the corpus, over 40 percent of the articles do not explicate the methodology they used to measure ideas. Those that do showcase methodological pluralism. Table 2 provides a brief overview of different methodologies used in the corpus depending on different conceptualisations of ideas, substituted by examples for each. Of the articles addressing methodology, most use a comparative or single case study research design. The majority relies on document analyses to derive ideas from, either speeches or policy documents. These data are often analysed through qualitative content analysis. Information about the nature of ideas is relatively scarce.

Table 2: overview of different types of research methods to measure ideas

\begin{tabular}{|c|c|c|c|}
\hline Approach & Specific method & Explanation & Example study \\
\hline \multirow[t]{4}{*}{$\begin{array}{r}\text { Ideas as } \\
\text { heuristics }\end{array}$} & $\begin{array}{l}\text { Operational Code } \\
\text { Analysis (OCA) }\end{array}$ & $\begin{array}{l}\text { Examining philosophi- } \\
\text { cal and instrumental } \\
\text { beliefs about the na- } \\
\text { ture of political life. }\end{array}$ & $\begin{array}{l}\text { Brummer (2016): verbal state- } \\
\text { ments of } 13 \text { political leaders to ex- } \\
\text { amine their beliefs about foreign } \\
\text { policy. }\end{array}$ \\
\hline & $\begin{array}{l}\text { Comparative Cogni- } \\
\text { tive Mapping (CCM): }\end{array}$ & $\begin{array}{l}\text { Analysing the web of } \\
\text { causal assertions an } \\
\text { individual makes on a } \\
\text { selected topic. }\end{array}$ & $\begin{array}{l}\text { Van Esch (2014): analyses the ide- } \\
\text { as of political leaders and central } \\
\text { bankers in the Eurozone crisis to } \\
\text { understand how the crisis affected } \\
\text { the economic and policy ideas of } \\
\text { these leaders. }\end{array}$ \\
\hline & Experiments & $\begin{array}{l}\text { Measurement of be- } \\
\text { liefs under controlled } \\
\text { conditions to discover } \\
\text { hypothesised effects. }\end{array}$ & $\begin{array}{l}\text { Renshon et al (2015): survey exper- } \\
\text { iment where respondents watched } \\
\text { different videos (relaxed, neutral } \\
\text { and anxious), and skin conduct- } \\
\text { ance tests measured emotional re- } \\
\text { sponses to questions about political } \\
\text { beliefs. }\end{array}$ \\
\hline & $\begin{array}{l}\text { Computational model- } \\
\text { ling }\end{array}$ & $\begin{array}{l}\text { Representations of } \\
\text { cognitive structures } \\
\text { and the processes that } \\
\text { link these structures } \\
\text { to decision }\end{array}$ & $\begin{array}{l}\text { Taber (1992): Use POLI, a model to } \\
\text { understand shared belief systems } \\
\text { to analyse U.S. Foreign Policy at the } \\
\text { level between individuals and or- } \\
\text { ganisations. }\end{array}$ \\
\hline
\end{tabular}




\begin{tabular}{|c|c|c|c|}
\hline & Surveys & $\begin{array}{l}\text { Analysis of self-re- } \\
\text { ported beliefs or ideas } \\
\text { about selected topics } \\
\text { using questionnaires }\end{array}$ & $\begin{array}{l}\text { Brewer and Steenbergen (2002): } \\
\text { survey of American citizens' show } \\
\text { reliance on beliefs about human na- } \\
\text { ture to reason about international } \\
\text { affairs. These beliefs help citizens } \\
\text { to make sense of topics that are } \\
\text { relatively unknown to them. }\end{array}$ \\
\hline & Interviews & $\begin{array}{l}\text { Structured, semi- } \\
\text { structured, or induc- } \\
\text { tive conversations, } \\
\text { targeted to uncover } \\
\text { self-reported assump- } \\
\text { tions, beliefs and ideas } \\
\text { of individuals. }\end{array}$ & $\begin{array}{l}\text { Radaelli and O'Connor (2009) use } \\
\text { INTUNE project data to uncover } \\
\text { shared governance belief systems } \\
\text { in different types of EU commit- } \\
\text { tees. }\end{array}$ \\
\hline & $\begin{array}{l}\text { Text analysis (qualita- } \\
\text { tive content analysis) }\end{array}$ & $\begin{array}{l}\text { Interpretation of the } \\
\text { ways in which individ- } \\
\text { uals, organisations or } \\
\text { members groups make } \\
\text { sense of who they are }\end{array}$ & $\begin{array}{l}\text { Foyle (1997) studies the normative } \\
\text { and practical beliefs of Eisenhower } \\
\text { and Dulles in offshore islands crisis, } \\
\text { observed in speeches, memoranda, } \\
\text { comments, letters. }\end{array}$ \\
\hline \multirow[t]{3}{*}{$\begin{array}{r}\text { Ideas as } \\
\text { institu- } \\
\text { tional } \\
\text { frame- } \\
\text { works }\end{array}$} & Critical policy analysis & $\begin{array}{l}\text { Examining histories/ } \\
\text { trajectory of larger } \\
\text { ideological contexts }\end{array}$ & $\begin{array}{l}\text { Widmaier (2016) unravels how } \\
\text { neoliberalism became embedded in } \\
\text { the US and the UK political system } \\
\text { by showing the 'journey' of the idea } \\
\text { into these political systems starting } \\
\text { from } 1970 \text { 's to the financial crisis in } \\
2008 \text {. }\end{array}$ \\
\hline & Case studies & $\begin{array}{l}\text { Investigating contem- } \\
\text { porary phenomena in- } \\
\text { depth within real-life } \\
\text { context. }\end{array}$ & $\begin{array}{l}\text { Becker and Hendriks (2008): influ- } \\
\text { ence of the Central Planning Bu- } \\
\text { reau in sustaining wage restraint } \\
\text { paradigm. }\end{array}$ \\
\hline & Content analysis & $\begin{array}{l}\text { Interpretation of the } \\
\text { ways in which individ- } \\
\text { uals, organisations or } \\
\text { members groups make } \\
\text { sense of who they are }\end{array}$ & $\begin{array}{l}\text { Bratberg's (2013): speech analysis } \\
\text { of Blair and Chirac in Iraq war to ob- } \\
\text { serve how their actions were guided } \\
\text { by pre-existing 'guiding principles' }\end{array}$ \\
\hline $\begin{array}{r}\text { Ideas as } \\
\text { strategic } \\
\text { tools }\end{array}$ & Discourse analysis & $\begin{array}{l}\text { Analysis of the sub- } \\
\text { stantive content of } \\
\text { ideas, and the interac- } \\
\text { tive processes of dis- } \\
\text { tributing these ideas } \\
\text { through discourse. }\end{array}$ & $\begin{array}{l}\text { Schmidt (2016): French Mont } \\
\text { Pélerin Society capacity to con- } \\
\text { struct and disseminate 'coordina- } \\
\text { tive discourse' of neoliberal think- } \\
\text { ing through their annual meetings. }\end{array}$ \\
\hline
\end{tabular}




\begin{tabular}{|c|c|c|}
\hline Process tracing & $\begin{array}{l}\text { Tracing causal chains } \\
\text { between two variables } \\
\text { using rich data (inter- } \\
\text { views, documents) }\end{array}$ & $\begin{array}{l}\text { Helgadottir (2016): process-tracing } \\
\text { of network of Italian economists } \\
\text { that erected and maintained the } \\
\text { idea of 'expansionary austerity'. }\end{array}$ \\
\hline Biographical analysis & $\begin{array}{l}\text { Analysis of biographi- } \\
\text { cal data (educational } \\
\text { background, country, } \\
\text { age) to measure the } \\
\text { proportion/presence } \\
\text { of certain ideas in } \\
\text { specified groups. }\end{array}$ & $\begin{array}{l}\text { Nelson (2014): database of bio- } \\
\text { graphical data (educational back- } \\
\text { ground, work experience) on } 2000 \\
\text { policy officials working with the } \\
\text { IMF to show proportion of neolib- } \\
\text { eral ideas in the organisation. }\end{array}$ \\
\hline $\begin{array}{l}\text { Narrative analysis / } \\
\text { Text analysis }\end{array}$ & $\begin{array}{l}\text { Methods aimed to } \\
\text { identify the '...reper- } \\
\text { toires, or shared pat- } \\
\text { terns of interpreta- } \\
\text { tion, active processes } \\
\text { of reasoning that } \\
\text { draw attention to the } \\
\text { form as well as con- } \\
\text { tent of argumentation } \\
\text { and can be linked to } \\
\text { broader social and po- } \\
\text { litical structures and } \\
\text { processes.' (Finlayson } \\
\text { 2004: 539). }\end{array}$ & $\begin{array}{l}\text { Alceste software to analyses the- } \\
\text { matic classes in rhetoric of speech- } \\
\text { es by Bush and Kerry (Schonhardt- } \\
\text { Bailey, 2005). }\end{array}$ \\
\hline
\end{tabular}

\section{Source: The Author}

Cognitive-ideational studies employ methods such as operational code analyses, experiments, surveys, or cognitive mapping, aiming to assess the cognitive processes that lay bare or influence an actor's or actors' beliefs about certain subjects (Table 2). Research questions focus on the causal links between contextual factors, personal disposition, and cognitive beliefs of policy actors and how these may affect policymaking.

Scholars approaching ideas as strategic tools employ methods that uncover either 1 ) the structural composition of networks, 2) the presence of a certain discourse in an organisation or in rhetoric, or 3) the propagators (i.e. policy entrepreneurs) and followers of a certain idea. Methodologies include process tracing, discourse analysis, or biographical analysis. These methods aid scholars to examine compositions of committees, research units, policy/epistemic communities, advocacy coalitions, and think tanks, as well as their analyses of how dominant narratives and discourses can be traced in these groups (see Campbell \& Pedersen, 2015; Radaelli \& O’Connor, 2009).

Institutional analysts of ideas use methods to explain the longitudinal processes of how ideas gain or lose acceptance in policy communities or society. These can be categorised under the heading of 'critical policy analysis', for example story-telling or historical analyses. These studies often contributed to theory-building in ideational scholarship. 
While the aforementioned methodologies can be used to study ideas, not all are designed to do so. This obfuscates empirical research in dissecting how ideas can be separated from other influential factors in the policy process. Of the reviewed methods, only cognitive mapping and operational code analysis were originally designed to study ideas. Hence, ideational scholarship would benefit from methodological innovation and rigorous application of such and other methodologies. Process-tracing, for example, addresses some of the challenges regarding the study of ideational causation (Jacobs, 2015; Molthof, 2016). It is a useful method to study the development of a policy domain over a long timespan. Discourse Network Analysis (DNA) provides insights into both the composition of actors in a discursive network, as well as the content of the ideas that they exchange in it (Leifeld, 2016), combining actor-centred and content-centred approaches. Comparative Cognitive Mapping (CCM) is useful to systematically measure ideas of actors or groups, allowing scholars to trace different forms of ideas, establish their strength, and compare ideas over time (Van Esch \& Snellens, 2019). Furthermore, Qualitative Comparative Analysis (QCA) is useful to assess configurational hypotheses of different factors and mechanisms of ideational change. Nonetheless, these methods have their limitations as well. They may be labour-intensive, or face challenges regarding validity and reliability of the analysis. As general advice, scholars need to consider the relationship between their level of analysis and the most appropriate research method carefully.

\section{Conclusion}

This paper demonstrated that ideational scholarship in public policy evolved along several distinct lines of inquiry. These lines range from micro-level cognitive ideational analysis, mesolevel discursive ideational analysis and macro-level institutional ideational analysis. It provides students and scholars of public policy with an approach to organise the existing literature and a language to explicate choices when choosing to work with ideational variables in public policy research. In effect, it enables us to provide answers to the question of how ideas matter. I also identified several blind spots in the existing scholarship. Here, I articulate what new directions are needed to address these.

First, although many scholars acknowledge that cognition plays a role in ideational scholarship, the role of cognition of individual actors in public policy is currently understudied. To better understand the percolation of ideas in policy, these micro-level cognitive dynamics should be brought back into the focus where Simon once put them (Kamkhaji \& Radaelli, 2019).

Second, scholars need to theorise and examine the relationships between the three functions ideas have: as heuristics, strategies or frameworks. For example, to what extent are policy and political entrepreneurs successful in shaping policy agendas when they advance wholly novel, frame-breaking ideas, as opposed to pre-existing but repackaged ideas that fit more within existing institutional discourses (Béland \& Waddan, 2015)? Examining such questions requires rigorous concept formation and testing. Early efforts to do so include Van Esch et al. (2018) and Swinkels (2020), who studied how Keynesian and ordoliberal paradigmatic ideas are reflected as beliefs in political leaders' speeches, using CCM to determine if such individually held paradigmatic beliefs changed over time. Likewise, Molthof (2016) applied process tracing, showing how political "actors strategically tailor their discursive use of ideas according to the political context and the policy position to be justified" (Molthof, 2016, p. 204). This enabled him to pin down the exact moment when actors transition from being 'mere slaves' of institutionalised ideas to using them strategically in political discourse and, ultimately, to reshape policies. 
Third, this paper suggests that ideational change could be considered a 'layered' process; therefore ideational scholarship needs studies that specify the mechanisms and sequences involved. An example of such an approach is Rinscheid et al.'s (2020) model that shows how and when different factors and mechanisms align to trigger a 'joint belief shift' among (a coalition of) policy actors during an exogenous shock (scoping condition), which then enables institutional change. The broad overview of triggers and constraints presented in this review (see Table 1) encourages public policy researchers to test a configuration of variables to explain the development of ideas as well as the relationship between ideas and policy changes. Swinkels' (2020) qualitative comparative analysis of the belief changes of key leaders in the Eurozone crisis is an example of a study that assesses the configurational hypotheses of individual belief changes during a crisis.

Fourth, scholars of ideas can benefit from expanding their 'methodological toolbox' to measure ideas. Policy science scholars have recently started using experiments, seen as a useful addition to the methodological toolbox for scholars doing cognitive-ideational research in a controlled setting (Grimmelikhuijsen et al., 2017). Diary studies and 'political ethnography' (Kamkhaji \& Radaelli, 2019) are potentially useful methods to study the dynamics of beliefs and arguments in policy arenas (Bevir \& Rhodes, 2015). Likewise, by using social network analysis methodology, Flickenschild and Afonso (2019) successfully demonstrate how the network structure of economists in both Germany and the United States impacted the diffusion of economic ideas during the Great Recession. Using computational text analysis methods, scholars like Rodman (2019) demonstrated how the idea of 'equality' changed in US media discourse over time from 1855.

Fifth, comparative studies of ideational change across different political systems, layers of government, and policy domains expose the limitations of the grand theories of radical policy change and the importance of middle-range, contingent theorising about ideational change (Baker, 2013). Future studies should therefore examine the multiple ways in which ideational change occurs in different policy settings (Radaelli \& O'Connor, 2009; Saurugger, 2013). Different settings may determine when a particular mechanism for change is more or less likely to be activated. For example, under similar conditions of a crisis such as COVID-19, ideational change at the level of national governments may be triggered by different mechanisms than ideational change at the EU level. As states have modes of centralisation, ideational change may be triggered by exogenously motivated mechanisms, such as powering or coercion, as central actors can weigh in their interests. Alternatively, in the EU, where decision-making authority and resources in times of crisis are dispersed, such centralised decision-making structures often take time to develop. Hence, persuasion or socialisation may be more prevalent mechanisms in these settings.

Finally, this paper attempted to systematically track how different kinds of ideas, mechanisms, and factors involved in ideational change matter in public policy. One limitation of this review may be that it focused on a narrow search scope related to the concept of ideas (cf. beliefs, paradigms, worldview, ideas), whereas the literature on 'ideational elements' (cf. Berman, 2013) includes other concepts such as memes, narratives and frames. Future literature reviews may benefit from including such a wide range of search terms to allow for a broader perspective on the concept of ideas. 


\section{Bibliography}

Baker, A. (2013). The New Political Economy of the Macroprudential Ideational Shift. New Political Economy, 18(1), 112-139.

Baker, A. (2015). Varieties of Economic Crisis, Varieties of Ideational Change: How and Why Financial Regulation and Macroeconomic Policy Differ. New Political Economy, 20(3), 342-366.

Baker, A., \& Underhill, G. R. D. (2015). Economic Ideas and the Political Construction of the Financial Crash of 2008. British Journal of Politics and International Relations, 17(3), 381-390.

Baumgartner, F. R. (2014). Ideas, paradigms and confusions. Journal of European Public Policy, 21(3), 475-480.

Beach, D., \& Pedersen, R. B. (2013). Process-Tracing Methods: Foundations and Guidelines. Michigan: The University of Michigan Press.

Becker, U., \& Hendriks, C. (2008). “As the Central Planning Bureau says”. The Dutch wage restraint paradigm, its sustaining epistemic community and its relevance for comparative research. Review of International Political Economy, 15(5), 826-850.

Béland, D. (2016). Kingdon Reconsidered: Ideas, Interests and Institutions in Comparative Policy Analysis. Journal of Comparative Policy Analysis, 18(3, SI), 228-242.

Béland, D., \& Cox, R. H. (2011). Ideas and politics in social science research. New York, NY: Oxford University Press.

Béland, D., \& Cox, R. H. (2016). Ideas as coalition magnets: coalition building, policy entrepreneurs, and power relations. Journal of European Public Policy, 23(3, SI), 428-445.

Béland, D., \& Waddan, A. (2015). Breaking down ideas and institutions: the politics of tax policy in the USA and the UK. Policy Studies, 36(2), 176-195.

Bell, S. (2012). The Power of Ideas: The Ideational Shaping of the Structural Power of Business. International Studies Quarterly, 56(4), 661-673. https://doi.org/10.1111/j.1468-2478.2012.00743.x

Bell, S., \& Hindmoor, A. (2015). Taming the City? Ideas, Structural Power and the Evolution of British Banking Policy Amidst the Great Financial Meltdown. New Political Economy, 20(3, SI), 454-474.

Berman, S. (2013). Ideational Theorizing in the Social Sciences since "Policy Paradigms, Social Learning, and the State." Governance, 26(2), 217-237.

Bevir, M., \& Rhodes, R. A. W. (Eds.). (2015). Routledge Handbook of Interpretive Political Science. London: Routledge.

Blyth, M. M. (2001). The Transformation of the Swedish Model: Economic Ideas, Distributional Conflict, and Institutional Change. World Politics, 54(1), 1-26.

Blyth, M. M. (2002). Great transformations: Economic Ideas and Institutional Change in the Twentieth Century. Cambridge: Cambridge University Press

Blyth, M. M. (2013). Austerity: the history of a dangerous idea. Oxford: Oxford University Press.

Bolsen, T., Druckman, J. N., \& Cook, F. L. (2015). Citizens', Scientists', and Policy Advisors' Beliefs about Global Warming. Annals of the American Academy of Political and Social Science, 658(1), 271-295. 
Bratberg, Ø. (2011). Ideas, tradition and norm entrepreneurs: Retracing guiding principles of foreign policy in Blair and Chirac's speeches on Iraq. Review of International Studies, 37(1), 327-348.

Brewer, P. R., \& Steenbergen, M. R. (2002). All against all: How beliefs about human nature shape foreign policy opinions. Political Psychology, 23(1), 39-58.

Brummer, K. (2016). "Fiasco prime ministers": leaders' beliefs and personality traits as possible causes for policy fiascos. Journal of European Public Policy, 23(5), 702-717.

Burdein, I., Lodge, M., \& Taber, C. (2006). Experiments on the automaticity of political beliefs and attitudes. Political Psychology, 27(3), 359-371.

Butler, L. D., Koopman, C., \& Zimbardo, P. G. (1995). The Psychological Impact of Viewing the film JFK - Emotions, Beliefs, and Political Behavioral Intentions. Political Psychology, 16(2), 237-257.

Cairney, P. (2019). Understanding Public Policy (2nd ed.). London: Red Globe Press.

Campbell, J. L., \& Pedersen, O. K. (2015). Policy ideas, knowledge regimes and comparative political economy. Socio-Economic Review, 13(4), 679-701.

Carstensen, M. B. (2010). The Nature of Ideas, and Why Political Scientists Should Care: Analysing the Danish Jobcentre Reform from an Ideational Perspective. Political Studies, 58(5), 847-865.

Carstensen, M. B. (2011a). Ideas are Not as Stable as Political Scientists Want Them to Be : A Theory of Incremental Ideational Change. Political Studies, 59, 596-615.

Carstensen, M. B. (2011b). Paradigm man vs. the bricoleur: bricolage as an alternative vision of agency in ideational change. European Political Science Review, 3(1), 147-167.

Carstensen, M. B. \& Matthijs, M. (2018). Of paradigms and power: British economic policy making since Thatcher. Governance, 31(3), 431-447.

Carstensen, M. B., \& Schmidt, V. A. (2016). Power through, over and in ideas: conceptualizing ideational power in discursive institutionalism. Journal of European Public Policy, 23(3, SI), 318-337.

Clements, B. (2012). The sociological and attitudinal bases of environmentally-related beliefs and behaviour in Britain. Environmental Politics, 21(6), 901-921.

Cox, R. \& Béland, D. (2013). The Politics of Policy Paradigms. Governance, 26(2), 193-195.

Crawford, N. C. (2016). What is war good for? Background ideas and assumptions about the legitimacy, utility, and costs of offensive war. British Journal of Politics and International Relations, 18(2), 282-299.

Culpepper, P. D. (2005). Institutional Change in Contemporary Capitalism: Coordinated Financial Systems since 1990. World Politics, 57, 173-199.

Daigneault, P., Jacob, S. \& Ouimet, M. (2012). Using systematic review methods within a Ph.D. dissertation in political science: challenges and lessons learned from practice. International Journal of Social Research Methodology, 17(3), 267-283.

Daigneault, P.-M. (2014a). Puzzling about policy paradigms: precision and progress. Journal of European Public Policy, 21(3), 481-484.

https://doi.org/10.1080/13501763.2014.893080

Daigneault, P.-M. (2014b). Reassessing the concept of policy paradigm: aligning ontology and methodology in policy studies. Journal of European Public Policy, 21(3), 453-469.

https://doi.org/10.1080/13501763.2013.834071

Duckitt, J., \& Fisher, K. (2003). The impact of social threat on worldview and ideological attitudes. Political Psychology, 24(1), 199-222. 
Dunlop, C. A., \& Radaelli, C. M. (2013). Systematising Policy Learning: From Monolith to Dimensions. Political Studies, 61(3), 599-619.

Dunlop, C. A., \& Radaelli, C. M. (2017). Learning in the bath-tub: the micro and macro dimensions of the causal relationship between learning and policy change. Policy and Society, 36(2), 304-319.

Fielding, K. S., Head, B. W., Laffan, W., Western, M., \& Hoegh-Guldberg, O. (2012). Australian politicians' beliefs about climate change: political partisanship and political ideology. Environmental Politics, 21(5), 712-733.

Finnemore, M. \& Sikkink, K. (1998). International Norm Dynamics and Political Change. International Organization, 52(4), 887-917.

Flibbert, A. (2006). The road to Baghdad: Ideas and intellectuals in explanations of the Iraq war. Security Studies, 15(2), 310-352.

Flickenschild, M., \& Afonso, A. (2019). Networks of economic policy expertise in Germany and the United States in the wake of the Great Recession. Journal of European Public Policy, 26(9), 1292-1311.

Foyle, D. C. (1997). Public opinion and foreign policy: Elite beliefs as a mediating variable. International Studies Quarterly, 41(1), 141-169.

Golec de Zavala, A., \& Van Bergh, A. (2007). Need for cognitive closure and conservative political beliefs: Differential mediation by personal worldviews. Political Psychology, 28(5), 587-608.

Grimmelikhuijsen, S., Jilke, S., Olsen, A. L., \& Tummers, L. (2017). Behavioral Public Administration: Combining Insights from Public Administration and Psychology. Public Administration Review, 77(1), 45-56.

Guth, J. L., Green, J. C., Kellstedt, L. A., \& Smidt, C. E. (1995). Faith and the Environment - Religgious Beliefs and Attitudes on Environmental Policy. American Journal of Political Science, 39(2), 364-382.

Hajer, M. (2013). Discourse Coalitions and the Institutionalization of Practice. In: Fischer, F. and Forester, J. The Argumentative Turn in Policy Analysis and Planning (pp. 43-76). Durham, NC and London: Duke University Press

Hajer, M., \& Wagenaar, H. (2003). Deliberative Policy Analysis: Understanding Governance in the Network Society. Cambridge: Cambridge University Press.

Haklai, O. (2003). Linking Ideas and Opportunities in Contentious Politics: The Israeli Nonparliamentary Opposition to the Peace Process. Canadian Journal of Political Science, 36(4), 791-812.

Hall, P A. (1993). Policy Paradigms, Social-Learning, and the State - The Case of Economic PolicyMaking in Britain. Comparative Politics, 25(3), 275-296.

Hay, C. (2011). Ideas and the Construction of Interests. In D. Beland \& R. H. Cox (Eds.), Ideas and Politics in Social Science Research (pp. 65-82). New York, NY: Oxford University Press.

Helgadottir, O. (2016). The Bocconi boys go to Brussels: Italian economic ideas, professional networks and European austerity. Journal of European Public Policy, 23(3, SI), 392-409.

Hogan, J., \& Howlett, M. (2015). Policy Paradigms in Theory and Practice. London: Palgrave Macmillan.

Hollis, M. (1994). The Philosophy of Social Science. The Philosophy of Social Science. Cambridge: Cambridge University Press.

Holsti, O. (1976). Foreign policy formation viewed cognitively. In R. M. Axelrod (Ed.), Structure of decision. The cognitive maps of political elites (pp. 18-54). Princeton, NJ: Princeton University Press. 
Jacobs, A. M. (2009). How do ideas matter?: Mental models and attention in German pension politics. Comparative Political Studies, 42(2), 252-279.

Jacobs, A. M. (2015). Process Tracing in the Social Sciences: From Metaphor to Analytic Tool. In A. Bennett \& J. T. Checkel (Eds.), Process Tracing in the Social Sciences: From Metaphor to Analytic Tool (pp. 1-49). Cambridge: Cambridge University Press.

Jervis, R. (2006). Understanding beliefs. Political Psychology, 27(5), 641-663.

Jones, B. D. (2017). Behavioral rationality as a foundation for public policy studies. Cognitive Systems Research, 43, 63-75.

Kamkhaji, J. C., \& Radaelli, C. M. (2017). Crisis, learning and policy change in the European Union. Journal of European Public Policy, 24(5), 714-734.

Kamkhaji, J. C., \& Radaelli, C. M. (2019). Don't think it's a good idea! Four building sites of the "ideas school.". In Great Minds, Ideas, Events and People: Ideational Scholarship, Empirical Analysis, and Behavior. Montreal: ICPP4 conference.

Kingdon, J. W. (1984). Agendas, Alternatives, and Public Policies. Boston, MA: Little, Brown and Company.

Kuisma, M. (2013). Understanding Welfare Crisis - The Role of Ideas. Public Administration, 91(4, SI), 797-805.

Larson, D. W. (1994). The Role of Belief Systems and Schemas in Foreign-Policy Decision-Making. Political Psychology, 15(1), 17-33.

Lee, M. (2016). How many lightbulbs does it take to change the financial system? Economic ideas and financial regulation, 1846-2007. British Journal of Politics and International Relations, 18(4), 866-888.

Leifeld, P. (2016). Discourse Network Analysis: Policy Debates as Dynamic Networks. In J. N. Victor, A. H. Montgomery \& M. Lubell (Eds.), The Oxford Handbook of Political Networks. Oxford: Oxford University Press.

Mandelkern, R., \& Shalev, M. (2010). Power and the ascendance of new economic policy ideas: Lessons from the 1980s Crisis in Israel. World Politics, 62(3), 459-495.

Matthijs, M. (2016). Powerful rules governing the euro: the perverse logic of German ideas. Journal of European Public Policy, 23(3), 375-391.

McNamara, K. R. (1999). Consensus and constraint: Ideas and capital mobility in European monetary integration. Journal of Common Market Studies, 37(3), 455-476.

Mehta, J. (2011). The Varied Role of Ideas in Politics: From "Whether" to "How." In D. Beland \& R. H. Cox (Eds.), Ideas and Politics in Social Science Research (pp. 23-46). New York, NY: Oxford University Press.

Meyer, C. O., \& Strickmann, E. (2011). Solidifying Constructivism: How Material and Ideational Factors Interact in European Defence. Journal of Common Market Studies, 49(1, SI), 61-81.

Mintrom, M. (2015). Herbert A. Simon, Administrative Behavior: A Study of Decision-Making Processes in Administrative Organization. In M. Lodge, E. C. Page, \& S. J. Balla (Eds.), The Oxford Handbook of Classics in Public Policy and Administration (pp. 12-21). Oxford: Oxford University Press.

Molthof, L. H. (2016). Understanding the Role of Ideas in Policy- Making : The Case of Germany's Domestic Policy Formation on European Monetary Affairs. PhD Thesis, University of London. 
Morcol, G. (2001). Positivist beliefs among policy professionals: An empirical investigation. Policy Sciences, 34(3-4), 381-401.

Morrison, J. A. (2016). Shocking Intellectual Austerity: The Role of Ideas in the Demise of the Gold Standard in Britain. International Organization, 70(1), 175-207.

Moschella, M. (2015). The Institutional Roots of Incremental Ideational Change: The IMF and Capital Controls after the Global Financial Crisis. British Journal of Politics and International Relations, 17(3), 442-460.

Moyson, S. (2017). Cognition and policy change: the consistency of policy learning in the advocacy coalition framework. Policy and Society, 36(2), 320-344.

Moyson, S., Scholten, P., \& Weible, C. M. (2017). Policy learning and policy change: theorizing their relations from different perspectives. Policy and Society, 36(2), 161-177.

Nelson, S. C. (2014). Playing Favorites: How Shared Beliefs Shape the IMF's Lending Decisions. International Organization, 68(2), 297-328.

Parsons, C. (2007). How to Map Arguments in Political Science. New York, NY: Oxford University Press.

Parsons, C. (2016). Ideas and power: four intersections and how to show them. Journal of European Public Policy, 23(3, SI), 446-463.

Petridou, E., \& Mintrom, M. (2020). A Research Agenda for the Study of Policy Entrepreneurs. Policy Studies Journal, Epub ahead of publication.

Petticrew, M., \& Roberts, H. (2006). Systematic Reviews in the Social Sciences: A Practical Guide. Blackwell Publishing.

https://doi.org/10.1027/1016-9040.11.3.244

Pierson, P. (2000). Increasing Returns, Path Dependence, and the Study of Politics. The American Political Science Review, 94(2), 251-267.

Radaelli, C. M., \& O'Connor, K. (2009). How bureaucratic elites imagine Europe: towards convergence of governance beliefs? Journal of European Public Policy, 16(7), 971-989.

Renshon, J. (2009). When Public Statements Reveal Private Beliefs: Assessing Operational Codes at a Distance. Political Psychology, 30(4), 649-661.

Renshon, J., Lee, J. J., \& Tingley, D. (2015). Physiological Arousal and Political Beliefs. Political Psychology, 36(5), 569-585.

Rinscheid, A., Eberlein, B., Emmenegger, P., \& Schneider, V. (2020). Why do junctures become critical? Political discourse, agency, and joint belief shifts in comparative perspective. Regulation and Governance, 14(4), 653-673.

Rodman, E. (2019). A Timely Intervention: Tracking the Changing Meanings of Political Concepts with Word Vectors. Political Analysis, 28(1), 87-111.

Rohrschneider, R. (1993). Environmental Belief Systems in Western Europe - A hierarchical model of constraint. Comparative Political Studies, 26(1), 3-29.

Sabatier, P. A. (1988). An Advocacy Coalition Framework of Policy Change and the Role of PolicyOriented Learning Therein. Policy Sciences, 21(2/3), 129-168.

Sabatier, P. A., \& Weible, C. M. (2014). Theories of the Policy Process. Boulder, CO: Westview Press.

Saurugger, S. (2013). Constructivism and public policy approaches in the EU: from ideas to power games. Journal of European Public Policy, 20(6, SI), 888-906. 
Schmidt, V. A. (2008). Discursive Institutionalism: The Explanatory Power of Ideas and Discourse. Annual Review of Political Science, 11, 303-326. https://doi.org/10.1146/annurev.polisci.11.060606.135342

Schmidt, V. A. (2011). Discursive Institutionalism. In International Encyclopedia of Political Science (Vol. 1, pp. 683-685).

Schmidt, V. A. (2016). The Roots of Neo-Liberal Resilience: Explaining Continuity and Change in Background Ideas in Europe's Political Economy. British Journal of Politics and International Relations, 18(2), 1-20.

Schmidt, V. A., \& Thatcher, M. (2014). Why are neoliberal ideas so resilient in Europe's political economy? Critical Policy Studies, 8(3), 340-347.

Schon, D. A., \& Rein, M. (1995). Frame reflection: Toward the resolution of intractrable policy controversies. New York, NY: Basic Books.

Schonhardt-Bailey, C. (2005). Measuring Ideas More Effectively: An Analysis of Bush and Kerry's National Security Speeches. PS: Political Science \& Politics, 38(04), 701-711.

Shamseer, L., Moher, D., Clarke, M., Ghersi, D., Liberati, A., Petticrew, M., Stewart, L. A. (2015). Preferred reporting items for systematic review and meta-analysis protocols (PRISMA-P) 2015: elaboration and explanation. BMJ, 349.

https://doi.org/10.1136/bmj.g7647

Swinkels, M. (2020). Beliefs of political leaders: conditions for change in the Eurozone crisis. West European Politics, 43(5), 1163-1186.

Taber, C. (1992). Poli - an expert system model of United States Foreign Policy Belief Systems. American Political Science Review, 86(4), 888-904.

Trein, P., \& Vagionaki, T. (2020). Learning Heuristics, Polarization, and Salience : Ideas and Politics in the Policy Process. Paper in progress. Retrieved from https://www.philipptrein.com/wp-content/ uploads/2020/10/Subm_WEP_7.pdf. Accessed on 20-11-2020.

Van Eck, N. \& Waltman, L. (2018). Vosviewer Manual.

Retrieved from : http://www.vosviewer.com/documentation/Manual_VOSviewer_1.6.9.pdf on 2011-2020.

Van Esch, F. (2014). Exploring the Keynesian-Ordoliberal Divide. Flexibility and Convergence in French and German Leaders' Economic Ideas During the Euro-Crisis. Journal of Contemporary European Studies, 22(3), 288-302.

Van Esch, F., \& Snellens, J. (2019). From belief to behaviour. Using cognitive maps to test ideational policy explanations. In Great Minds, Ideas, Events and People: Ideational Scholarship, Empirical Analysis, and Behaviour. Montreal: ICPP4 conference.

Van Esch, F., Steenman, S., Joosen, R., Brand, L., \& Snellens, J. (2018). Making Meaning of the Eurocrisis. Deliverable 3.3 for the TRANSCRISIS Horizon2020 Project.

https://doi.org/10.13140/RG.2.2.33849.06247.

Van Esch, F., \& Swinkels, M. (2015). How Europe's political leaders made Sense of the Euro crisis: The influence of pressure and personality. West European Politics, 38(15), 1203-1225.

Widmaier, W. W. (2007). Where You Stand Depends on How You Think: Economic Ideas, the Decline of the Council of Economic Advisers and the Rise of the Federal Reserve. New Political Economy, 12(1), 43-59 
Widmaier, W. W. (2010). Emotions Before Paradigms: Elite Anxiety and Populist Resentment from the Asian to Subprime Crises. Millenium - Journal of International Studies, 39(1), 127-144.

Widmaier, W. W. (2016). The power of economic ideas through, over and in - political time: the construction, conversion and crisis of the neoliberal order in the US and UK. Journal of European Public Policy, 23(3, SI), 338-356.

Woods, N. (1995). Economic Ideas and International Relations : Beyond Rational Neglect. International Studies Quarterly, 39, 161-180.

Yee, A. S. (1996). The causal effects of ideas on policies. International Organization, 50(1), 69-108.

\section{Appendix}

\section{Review of the literature using PRISMA}

Peter Hall's (1993 > 7000 WoS citations as at September 2019) landmark article on policy paradigms and social learning spurred the academic debate on the role of ideas; other highly cited contributors - e.g. Finnemore and Sikkink (1998 > 7000), Schmidt (2008 > 2400), Blyth (2002 > 2000), and Pierson $(2000>7500)$ - followed suit. Capturing the hausse, this paper reviews the state of research on ideas and ideational change, guided by the PRISMA method (Petticrew and Roberts 2006). To get a comprehensive, structured, and systematic overview of a certain concept or a study domain, the PRISMA method can be a helpful tool. In this study, the method was used to get a first view of the subdiscipline-spanning literature regarding the concepts of ideas and ideational change. The PRISMA method requires the author to document the review process and code articles on a number of items (Petticrew \& Roberts, 2006; Shamseer et al., 2015). For this review, we first selected search terms for the search engines and defined eligibility criteria for inclusion of articles. The concept of 'ideas' was the core search term in publication titles and included frequently used synonyms - beliefs, belief-system, worldview, zeitgeist, paradigm - across the different subfields of political science.

As the study is primarily concerned with the role of ideas in politics and policy, these words were used as search terms in the publication topic (title, abstract and keywords). This included the frequently used variations and synonyms, e.g. policies. ${ }^{8}$ After defining the search terms, I carried out two searches. Peer-reviewed articles in English on the topic were sourced from the Web of Science SSCI collection (categories public administration, political science, and international relations) and the Scopus Social Sciences collection. Journals featuring five or more articles on the topic during January 1990 and January 2017 were included in the analysis. These searches resulted in 756 articles, of which 157 were duplicates.

Figure 1 shows the bibliometric network of the articles that resulted from the searches. It highlights the interconnectedness and differences between all journals in the SSCI and Scopus Social Science collection (Van Eck and Waltman, 2018). It discerns contributions in several subdisciplines (international studies and political psychology, public policy, politics and political economy, and public

8 - The search string used to collect the data in Web of Science was:

(TI=(idea* NOT ideal NOT idealism OR "beliefs" OR "belief-system*" OR paradigm* OR worldview OR zeitgeist) AND $\mathrm{TS}=$ (politics OR policy OR political OR policies) AND WC=(Political Science OR International Relations OR Public Administration)) AND DOCUMENT TYPES: (Article)

The search string to collect the data in Scopus was:

TITLE(Idea* AND NOT ideal AND NOT idealism OR "beliefs" OR "belief-system*" OR paradigm* OR worldview OR zeitgeist) AND TITLE-ABS-KEY(politics OR policy OR political OR policies) AND SCRTYPE(j) AND SUBJAREA(SOCI) AND PUBYEAR AFT 1989 AND LANGUAGE(English) 
administration) and shows how these are interconnected. The Journal of European Public Policy is revealed to be the key node in the network, being most densely connected to other journals. Figure 1 also shows there is virtually no interconnectedness between articles and journals that take a more agentic approach (e.g., in political psychology) towards ideas and those that take a more structural perspectives (e.g., in political economy) on ideas in politics and policy.

Figure 1. Bibliographic interconnectedness of journals in this review

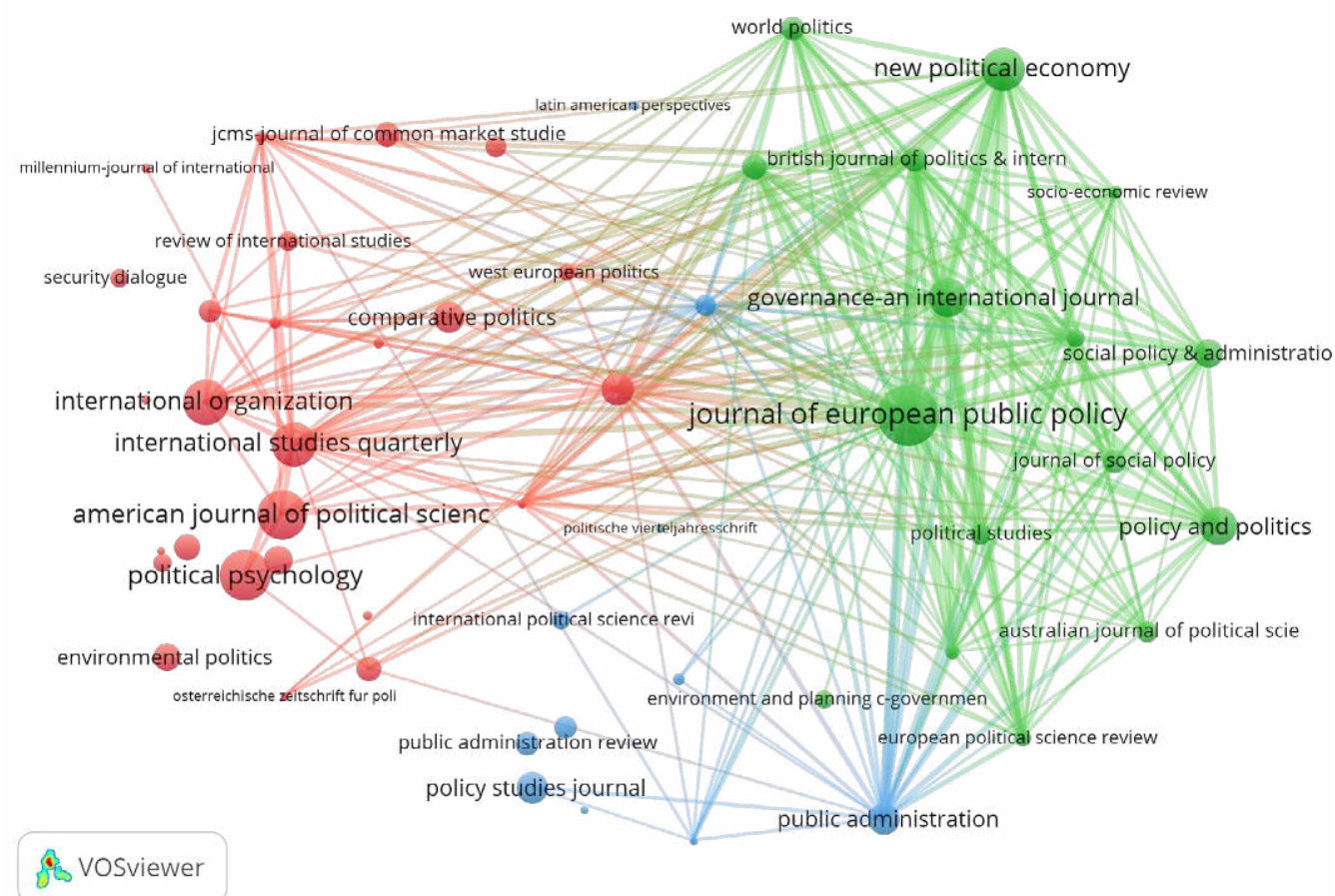

Of the remaining 599 articles, 52 abstracts and 15 full-texts were not available for screening. Eventually, 532 abstracts were screened and coded on inclusion criteria as 67 did not include an abstract or abstract was not accessible. The inclusion criteria were 1 ) a reference in the abstract to the concept of ideas (if possible explicit reference to ideas as a dependent variable), 2) a reference in the abstract to researching ideas (methodology), 3) a reference in the abstract to ideational change, and 4) a reference in the abstract to conditions that may cause ideational change.

A total set of 78 articles published in 27 different journals matched one or more of the inclusion criteria. These 78 articles were subsequently coded for full-text eligibility using coding criteria that focused on the key questions of the study: conceptualization of ideas, carriers and methods to research ideas, theories of ideational change and drivers of ideational change (see Table 1 for a full description of the codes used in this review). These four questions were derived from articles and book chapters discussing the challenges for ideational scholarship (cf. Daigneault, 2014b, 2014a; Mehta, 2011). 


\section{Figure 2. Growth of articles per year}

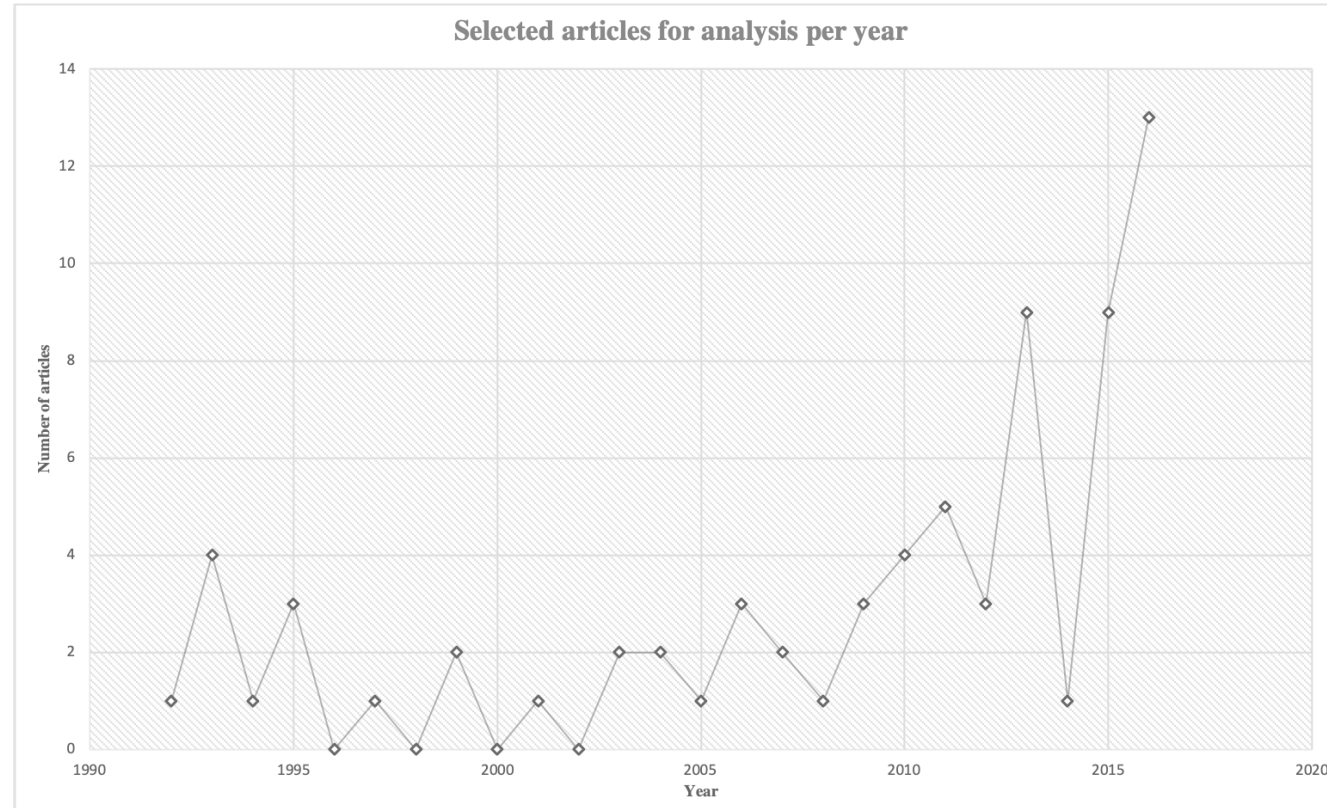

Ultimately, 71 articles were selected for full-text analysis. The remaining 7 were excluded because they ultimately did not focus around the key concept of the review $(n=3)$, were not presented in article format $(n=1)$ or full-texts were not readable $(n=4)$. After several conference workshops, relevant books, dissertations, and 'grey' literature were added. The chief objective was to capture the key debates and differences across different (sub)disciplines, not to compile an exhaustive corpus. Figure 1 depicts the 'ideational turn' in the growing number of articles published over time.

The remaining 71 articles were also coded for background factors, such as focus area, policy area, and article type. Furthermore, the institutional affiliation of the first author and the country of the institutional affiliation were coded. After the coding process, the first results were published at two different conferences. These sessions led to reviewing ten other books and publications that were used as complementary readings. The full selection process of articles is shown in figure 1.

Synthesizing the results of the articles in a systematic literature review can be done by either a quantitative meta-analysis or qualitative narrative analysis. Given the paper's aim of presenting a substantive review of current conceptualizations and theories of ideas, hypotheses and findings, I chose the narrative approach (Petticrew \& Roberts, 2006). ${ }^{9}$ A quantitative scoping of the background factors that were coded for all articles is presented below.

A systematic literature review on a fuzzy concept in the field of social sciences is a complex endeavour (Daigneault et al. 2012). Therefore, I want to stress that this study knows limitations. First, as the searches only include peer-reviewed published articles in journal, a pitfall is that newly published articles, conference proceedings, dissertations, books, or 'grey literature', were not included in the searches. Second, as this is a single-authored study, the articles were coded by one coder only which has the potential to lead to flawed coding. The researcher conducting the review did not have sufficient resources to hire research assistants to double the work. Third, defining the selection criteria (inclusion and exclusion of articles) for a review is a complex matter, and decisions in this stage can have consequences for the corpus as scholars can, for example, be easily overwhelmed by the

9 - Due to resource constraints the articles were coded by one coder. The coding sheet shows key insights about. 
sheer number of studies to screen. After deliberation with an advisory team, the search terms were defined in narrow rather than broad terms (focusing on ideas, beliefs, paradigms, instead of the breadth of ideational elements such as norms, frames, narratives, images). This may have excluded relevant articles, but as searching with these 'narrow' terms already led to $>500$ articles to screen, I believe that to keep such a review manageable for a sole author, these search terms have been sufficient to capture the state of the art in the current debate, spanning different subdisciplines. Future reviews could definitely benefit from expanding the scope of search terms. Taking these limitations into account, the results from the SLR provided a core corpus that served as a point of departure for the paper, yet additional references were included after conferences, over time, through feedback, and through reviews.

Figure 3. PRISMA Flow Diagram
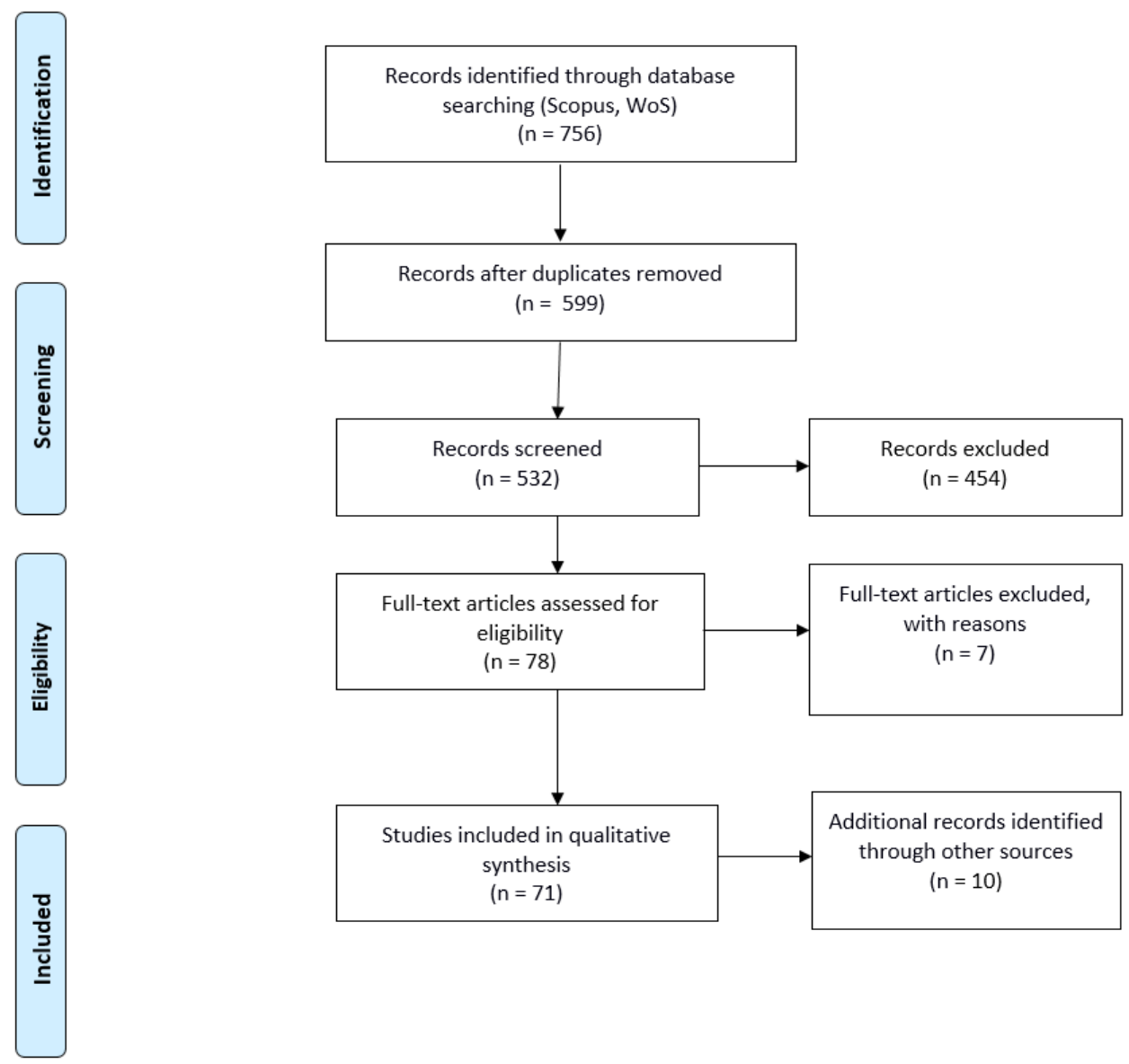


\section{Coding criteria for full-text articles}

\section{Table 1}

\begin{tabular}{|c|c|}
\hline INDICATOR & PURPOSE AND EXPLANATION OF CODES \\
\hline Year of publication & Numeric \\
\hline Author(s) & Last name(s) \\
\hline Journal name & Used to construct number of publications per year \\
\hline Title & Title: Subtitle \\
\hline $\begin{array}{l}\text { Institutional } \\
\text { affiliation }\end{array}$ & First author's institutional affiliation \\
\hline $\begin{array}{l}\text { Country of } \\
\text { publication }\end{array}$ & Country of the institution of the author \\
\hline $\begin{array}{l}\text { Conceptualization } \\
\text { category }\end{array}$ & $\begin{array}{l}\text { Recoded item after initial coding process. Used to calculate num- } \\
\text { ber of scholars in distinct disciplines/conceptual approaches } \\
\text { C. Constitutional } \\
\text { H. Heuristics } \\
\text { S. Strategic } \\
\text { M. Mixed }\end{array}$ \\
\hline $\begin{array}{l}\text { Conceptualization } \\
\text { / definition of ideas }\end{array}$ & Summary/excerpt from article about perception of the concept of ideas \\
\hline Carrier category & $\begin{array}{l}\text { Recoded item after initial coding process. Used to categorize and group the } \\
\text { general type of carrier of ideas. } \\
\text { G. Groups } \\
\text { S. Structure } \\
\text { I. Individual } \\
\text { M. Mixed }\end{array}$ \\
\hline Carrier(s) & $\begin{array}{l}\text { Who or what scholars identify as ultimate carrier or champion of ideas in } \\
\text { their study }\end{array}$ \\
\hline $\begin{array}{l}\text { Category taxonomy } \\
\text { of change }\end{array}$ & $\begin{array}{l}\text { Recoded item after initial coding process: used to distinguish between } \\
\text { scholars using different taxonomies of ideational change and provide quan- } \\
\text { titative evidence as to how much follow in one category or another. Codes: } \\
\text { Hierarchical } \\
\text { Incremental } \\
\text { Mixed } \\
\text { Unclear }\end{array}$ \\
\hline $\begin{array}{l}\text { Change (speed, pro- } \\
\text { cess, direction) }\end{array}$ & $\begin{array}{l}\text { Notes or excerpts from original articles about the concept of change. Aim } \\
\text { here was to see how scholars write about change, possibly distinguish be- } \\
\text { tween the speed of change (fast/slow), the process (revolutionary or evo- } \\
\text { lutionary), and the direction of change (reinforcement, conversion, stasis, } \\
\text { etc.) }\end{array}$ \\
\hline
\end{tabular}




\begin{tabular}{|c|c|}
\hline $\begin{array}{l}\text { Triggers/ } \\
\text { constraints }\end{array}$ & $\begin{array}{l}\text { Notes or excerpts from text to delineate and categorize the different in- } \\
\text { dependent or mediating variables that are expected to affect ideational } \\
\text { change. Also includes references to the mechanisms that lead to change } \\
\text { (such as learning, persuasion, or socialization). }\end{array}$ \\
\hline \multirow[t]{2}{*}{ Focus area } & Codes: International, Comparative, European, National, Regional. \\
\hline & $\begin{array}{l}\text { Used to understand the focus of empirical puzzles/studies of the included } \\
\text { articles. }\end{array}$ \\
\hline \multirow[t]{2}{*}{ Locus category } & $\begin{array}{l}\text { C: climate; E: economic/financial; F: foreign policy; L: leadership studies; G: } \\
\text { governance; W: welfare policy; I: immigration policy; P: political philoso- } \\
\text { phies; n.a.: Not applicable. }\end{array}$ \\
\hline & Used for quantitative scoping to count the different (policy) domains \\
\hline Locus area; & $\begin{array}{l}\text { Inductive coding of the different policy domains or topics to understand in } \\
\text { what policy subfields research on ideas is most prevalent or to see if concep- } \\
\text { tualizations of ideas and change differ per subdomain. }\end{array}$ \\
\hline \multirow[t]{6}{*}{ Article type; } & Empirical \\
\hline & Methodological \\
\hline & Theoretical \\
\hline & Introduction to special issue \\
\hline & Theoretical and empirical \\
\hline & $\begin{array}{l}\text { N.B. For articles coded as theoretical or introduction to special issue, the } \\
\text { subsequent methodology code was not applied. }\end{array}$ \\
\hline \multirow[t]{2}{*}{ Methodology } & $\begin{array}{l}\text { Inductive coding of methods used in the different articles to uncover how } \\
\text { scholars aim to study ideas. N.A. when articles did not contain methodol- } \\
\text { ogy }\end{array}$ \\
\hline & Unspecified when methodology was not made explicit \\
\hline $\begin{array}{l}\text { Main argument, } \\
\text { insights and } \\
\text { conclusion }\end{array}$ & $\begin{array}{l}\text { Excerpts from article text or notes that centre around the key question of } \\
\text { the article, its main insights and the conclusions. }\end{array}$ \\
\hline $\begin{array}{l}\text { Further } \\
\text { research questions }\end{array}$ & $\begin{array}{l}\text { Used for drafting concluding section on future research agenda for idea- } \\
\text { tional scholarship. }\end{array}$ \\
\hline
\end{tabular}

\section{Quantitative scoping}

\section{Institutional affiliation and country of publication}

The majority of the studies are conducted by scholars affiliated to institutions in the United States $(\mathrm{n}=31)$ and the United Kingdom $(\mathrm{n}=12)$. Scholars residing at institutions in Australia, Canada and Denmark follow suit $(6 ; 6 ; 5)$. The remainder of the articles are published by scholars spread throughout Europe, in Austria ( $n=1)$, Germany $(n=1)$, The Netherlands $(n=1)$, Italy $(n=1)$, Norway $(n=2)$, and France $(n=1)$. One article comes from scholars in the Middle East (Israel, $n=1)$. In three articles we could not identify the institutional affiliation on the basis of the article.

We can observe an underrepresentation of European institutions in the literature in the set, and an overrepresentation of scholars residing in English speaking countries (USA, UK, Australia and Canada). Turning to institutions, the Australian National University ( $n=3)$, University of Aalborg 
( $n=3)$, Queens University Belfast ( $\mathrm{n}=3$ ), University of Queensland ( $\mathrm{n}=3$ ), and the University of Saskatchewan $(n=4)$ appear three or more times in the set. These first findings do suggest that ideational scholarship may be dominated by scholars based in English speaking countries and institutions.

\section{Focus area and topics}

Of the articles published in English-speaking countries ( $n=55)$, the majority focuses on the national level (36.4\%). Specifically, the domains under investigation in these articles range from migration policy, economic policy, US leadership, a country's foreign policy, or climate change. Fewer articles published in English-speaking countries focus on the European level (14.5\%). Of these, the articles focus on Eurozone governance, financial regulation, economic integration, or EMU. Another 14.5\% of the studies is coded having comparative focus, focusing on the topics of environmental policy, political economy, welfare state reform, tax policy or war studies/foreign policy. $10.9 \%$ of the articles by scholars based in English-speaking institutions focus on the international level, for example on the International Monetary Fund (IMF), foreign policy, or international political economy. The remaining $23.6 \%$ of these articles are either theoretical or methodological in nature and as such do not focus on one specific focus area or policy domain.

Scholars based in Non-English, European research institutions, do not focus more on the EU level. Two studies focus on EU welfare state reform and European integration respectively. Another five articles zoom in on the comparative national, or international level and topics under study here are foreign policy $(n=2)$, welfare state reform $(n=1)$, wage restraint $(n=1)$ and international monetary finance $(n=1)$. Again, a fair share of the articles here $(n=5)$ is more theoretical in nature.

For all studies combined, we can conclude that most studies in our full set $(n=71)$ either focus on the national level ( $\mathrm{n}=27 ; 38.0 \%)$ or do not have a specific focus $(\mathrm{n}=18 ; 25.4 \%)$. Relatively few are focused on comparison, international relations or EU studies ( $n=9,12.7 \% ; n=7,9.9 \% ; n=10,14.0 \%)$. The locus areas (subdisciplines, policy domains) are quite diverse and specific. Figure 2 presents an overview of all studies per locus area. Most articles in our set focus on the realm of economic of financial policy, or foreign policy (31\%), another $27 \%$ is do not focus on a specific topic as they are more theoretical in nature.

Figure 1: locus areas of studies in set

Locus areas of studies in set $(\mathrm{n}=71)$

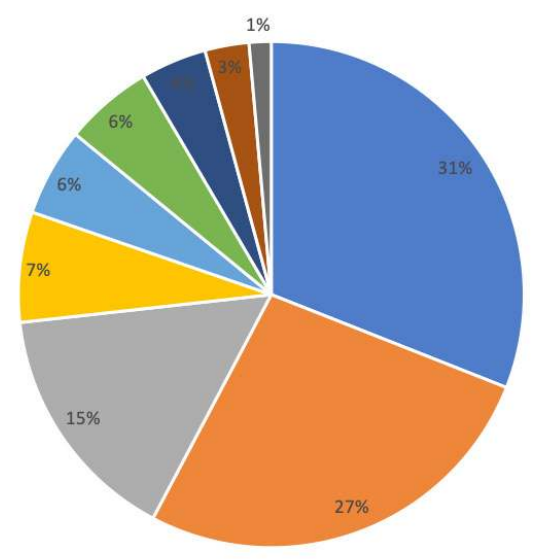




\section{Journals}

In the main text, we have showed how articles were connected and distributed over our search results $(n=532)$. More specifically, for the included articles in our set, the journal distribution is presented in figure 3. We can observe that the Journal of European Public Policy (JEPP), the British Journal of Politics and International Relations (BJPIR) and the Journal of Political Psychology (PP) are most frequent in our set.

Figure 2. Number of articles per journal.

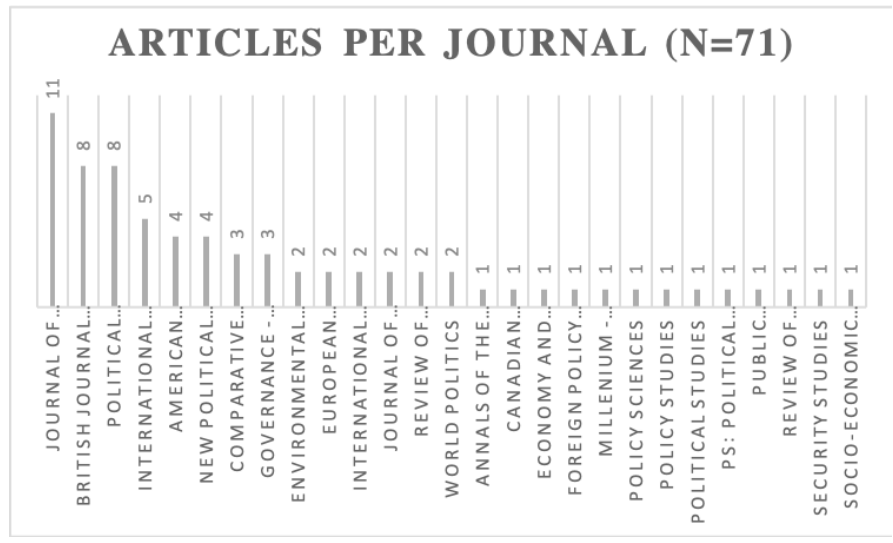

\section{Article type and methodology}

We have elaborated extensively on the different, specific types of methodologies and research practices in the main text of this article. However, all articles were also coded with regard to article type. First, articles coded as empirical contain studies that focus more on a rich description or explanation of empirical data, and make more limited use of theoretical concepts. Of the articles included in our set, $40.8 \%$ were coded as empirical. Second, $14.1 \%$ of the articles were coded as purely theoretical. This means that these have an explicit theoretical focus. Furthermore, $36.6 \%$ were coded as theoretical, supported by empirical evidence. These studies often have an explicit theoretical grounding, and focus on the presentation of a theoretical argument. To make the case for the theoretical argument, these studies use empirical data to illustrate the relevance of the theories they are describing. For these studies, it is often difficult to establish the methodological quality of the studies and processes of data collection. In sum, over $50 \%$ of the articles were more theoretical than empirical in nature. A further $4.2 \%$ of the article were about methodological innovations or explanations, and another $4.2 \%$ were introductions or commentaries for special issues/sections in journals. 